\title{
الغياب عن العمل الوظيفي وأثره في استحقاق الراتب \\ دراسة فقهية
}

\author{
'ميود محد علي الزمناكويي' \\ ' قسم الدراسات الاسلامية، كلية العوم الاسلامية، جامعة صلاح الدين، اربيل، اقليم كردسثان، العراق
}

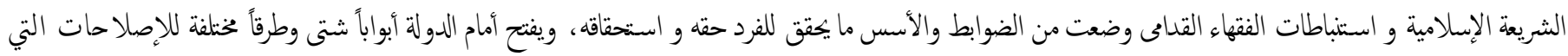

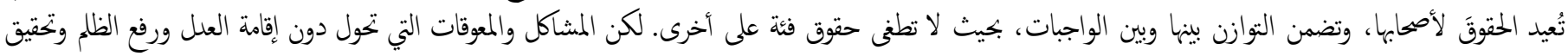

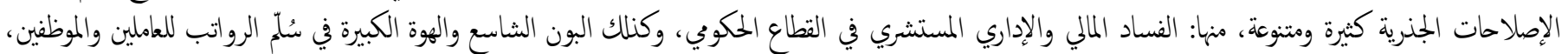

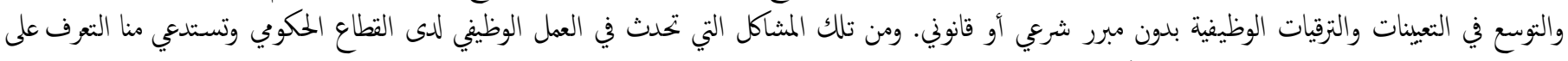

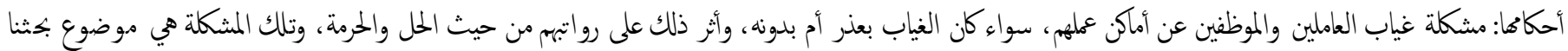

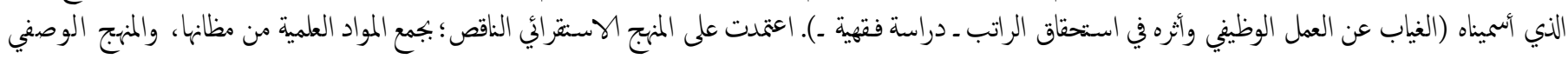

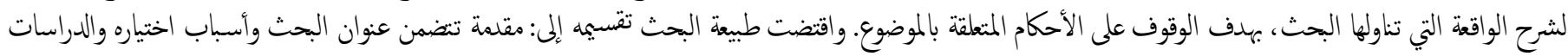

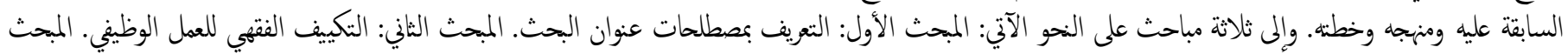

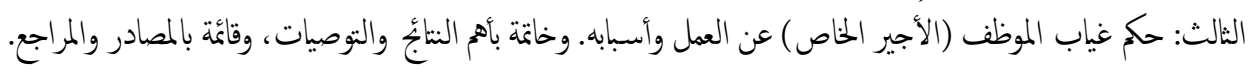
مفاتيح الكلمات: الغياب، العمل الوظيفي، الراتب، الأجير الخاص، الأجرة

تعيد الأمور إلى مجارها والحقوق إلى أصحابها، وبنلك يقام العلل ويتلاشى الظلم ويتحقق التوازن بين الحقوق و الواجبات.

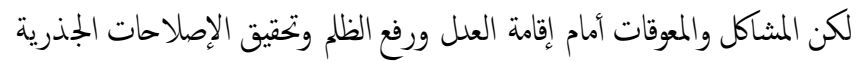

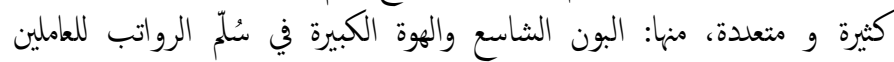
والموظفين في القطاع الحكوي، ومنها التوسع في التعيبنات والترقيات الونيات الوظيفية.

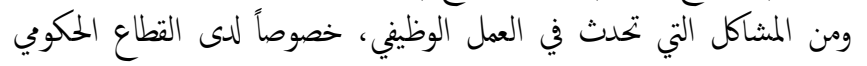

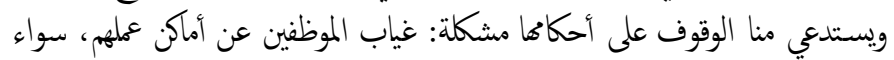

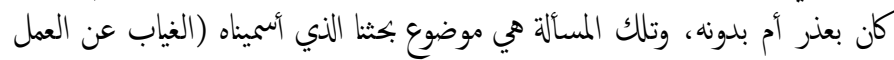
الوظيني وأثره في استحقاق الراتب ـ دراسة فقهية ـ).

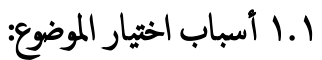

I. تبيين ما تميزت به الشريعة الإسلامية واستنباطات الفقهاء من رصانة ومرونة وقدرة فائقة على سنّ ضوابط وقوانين وأنظمة تضمن التوازن بين حقوق العحال

والموظفين وبين واجبانهم.

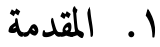

المحمد الله والصلاة والسلام على رسول الله صلى وعلى آله وأصحابه ومن اتبع هداه إلى يوم الدين. أما بعد:

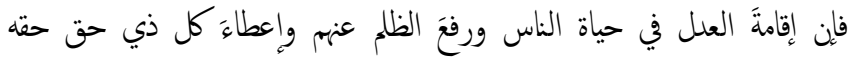

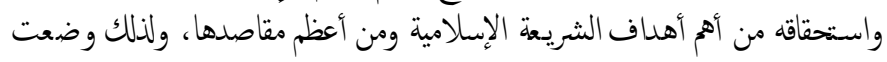

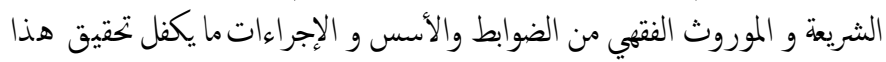

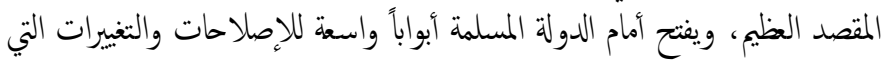

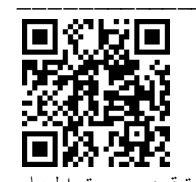

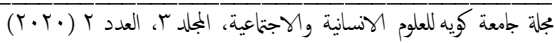

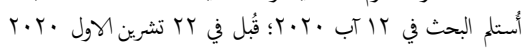

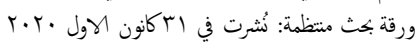

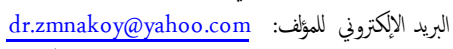

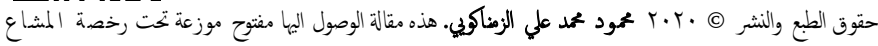
الإبداعي النسبية -CC BY-NC-ND 40. 
أما المراد بالغياب اصطلاحاً فيُّصَد به هنا: ألاّيّضر الموظف في مكان عمله لأداء

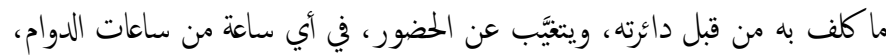

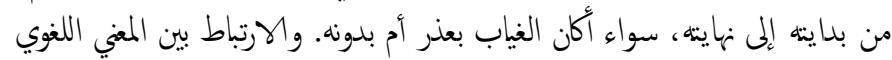
والمعني الاصطلاحي واضح، غير محتاج إلى إيضاح.

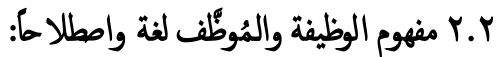

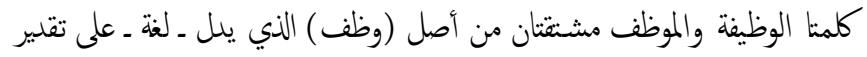

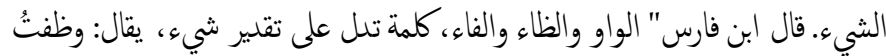

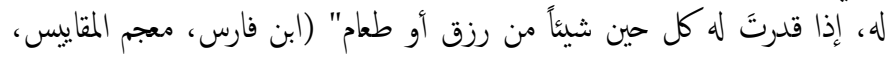

. (ITY/T

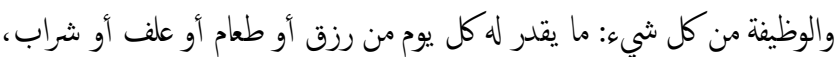

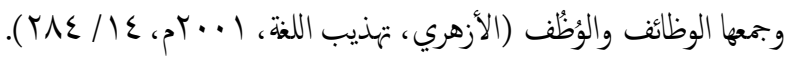

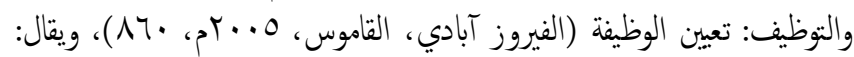

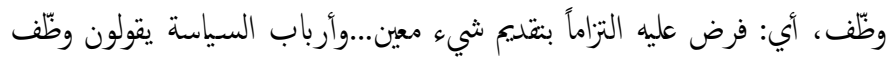

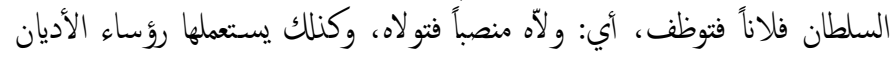

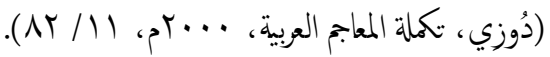

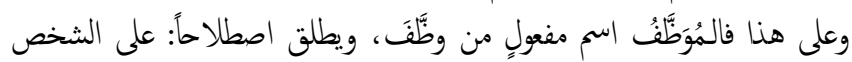

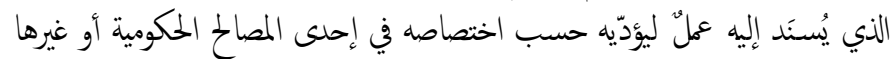

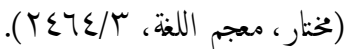

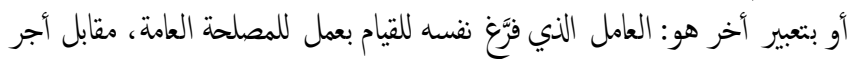

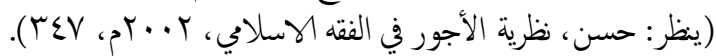

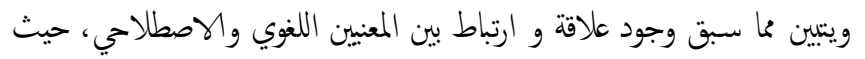

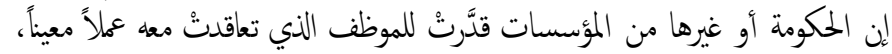

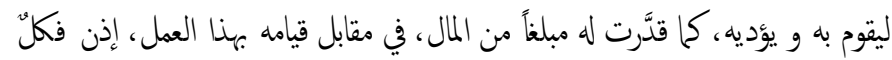

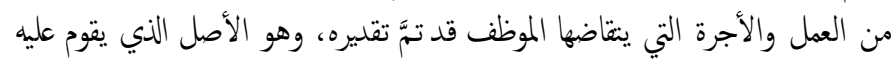

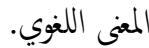

\section{r.Y. I. مفهوم الاستحقاق لغة واصطلاحك:}

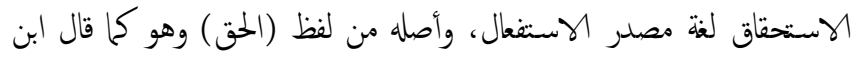

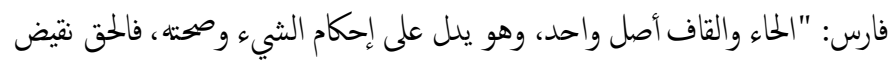

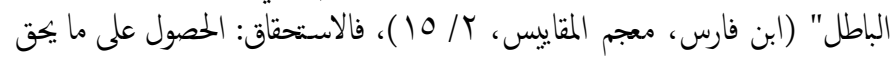

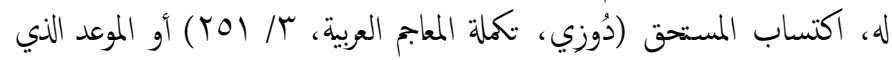

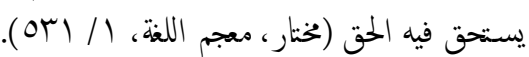

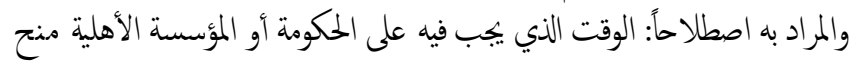

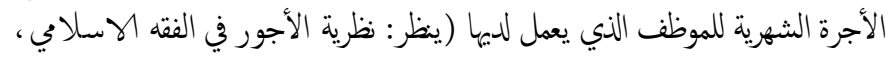

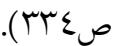

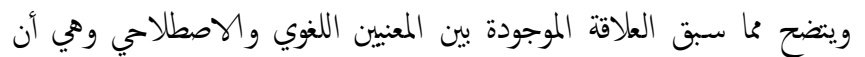

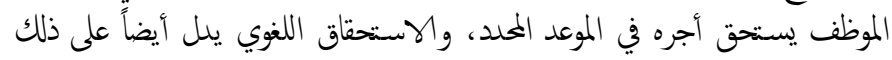
الموعد الذي يحق لصاحب الحق الحصول على حقه فيه.

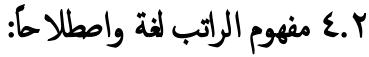

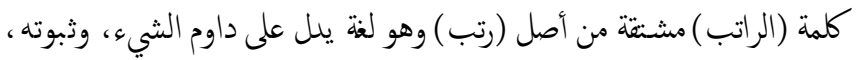

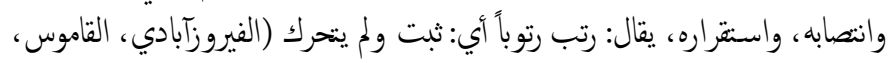

r. توعية المسلمين بالأحكام الشرعية فيا يتعلق بموضوع غياب الموظفين عن أماكن

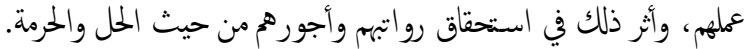

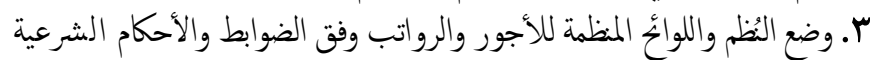

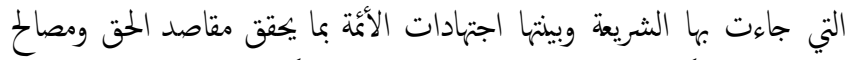
الخلقق، وعدم توكيل الأمر إلى أهواء الحكام وضمائر المحكومين.

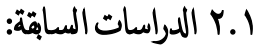

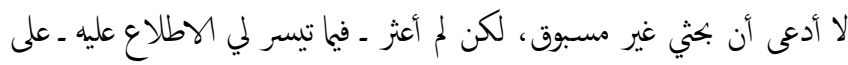

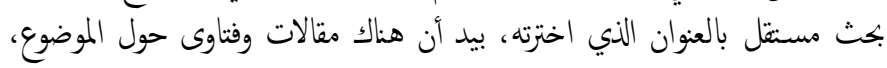

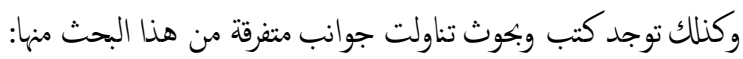

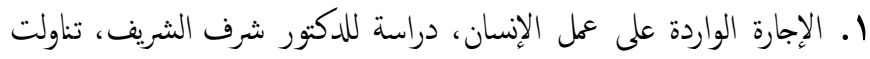

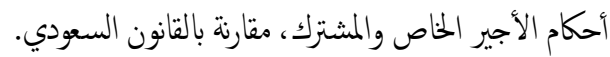

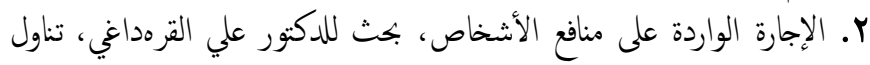

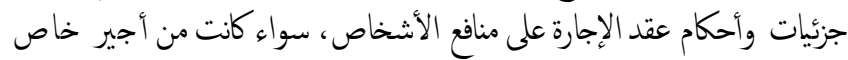

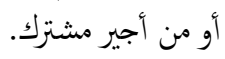

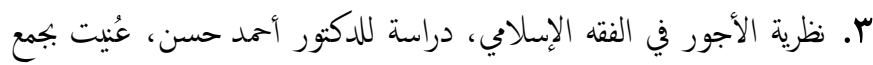

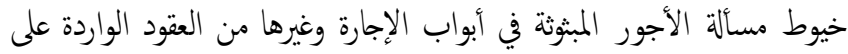

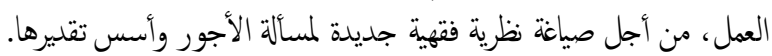

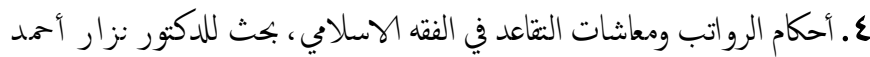

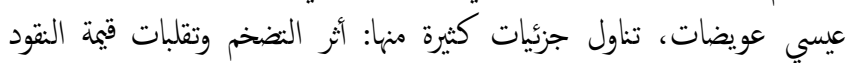

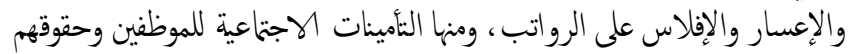
المالية وأسس تقديرها وغير ذلك.

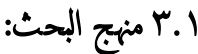

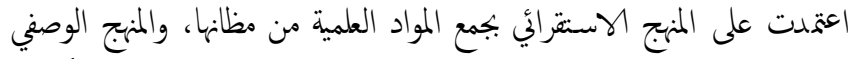

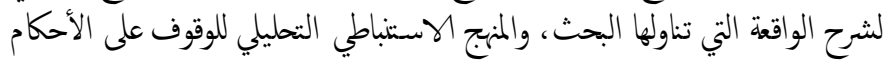
المتعلة بالموضوع.

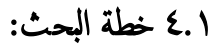

واقتضت طبيعة البحث تقسيمه إلى مقلمة، و ثلاثة مباحث، و خاتمة بأهم النتائح والتوصيات، وقائمة بالمصادر والمراجح.

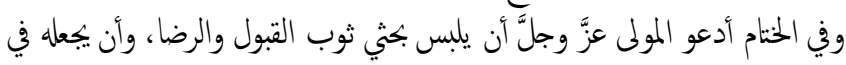

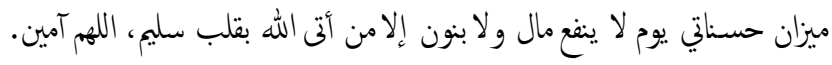

\section{r. التعريف بصطلحات عثوان البحث}

\section{r. (1. مفهوم الفياب لغة واصطلامة:}

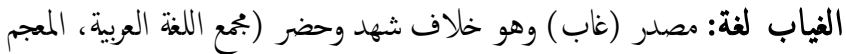

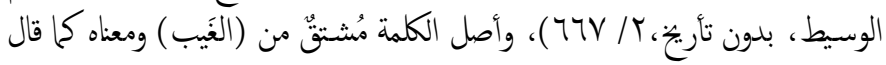

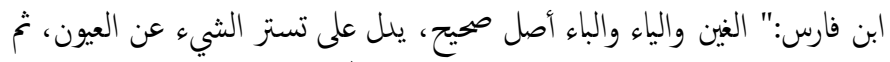

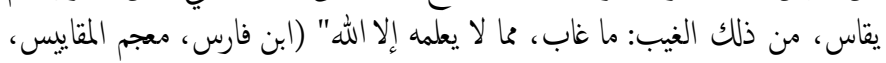

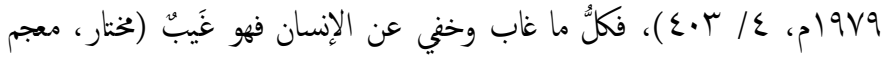

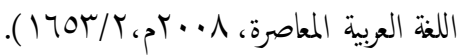


ينقل من سفينة وحيوان كالرواحل كزاء في الغالب فيها. الدردير ، الشرح الكبير، بدون

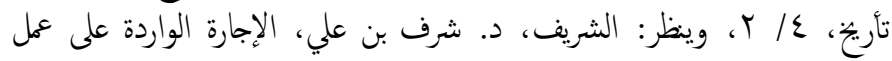

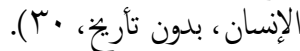

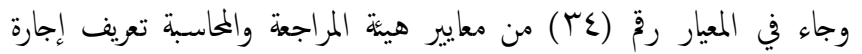

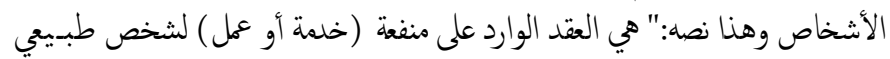

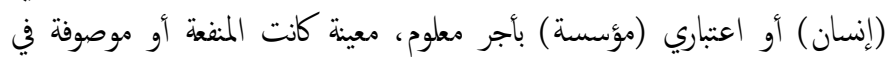

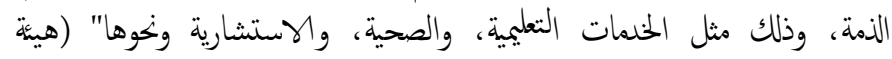

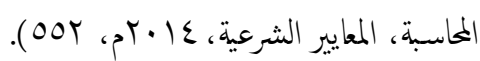

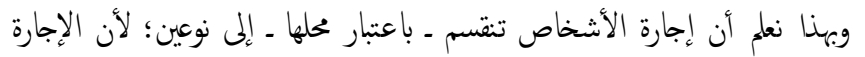

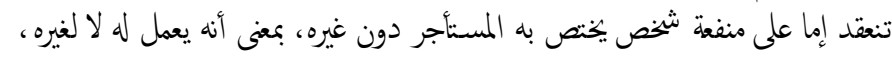

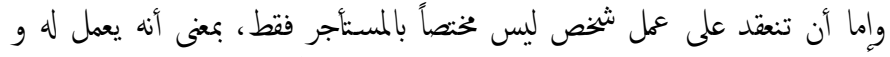
لغيره، لكن بعقود مختلفة، وسيأتي تعريف كلا لان النوعين قريباً.

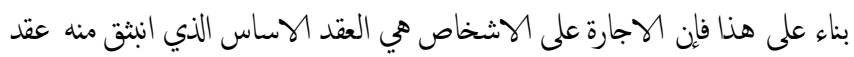

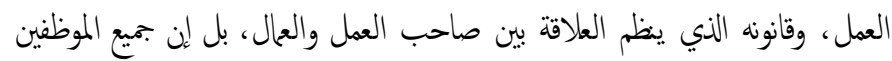

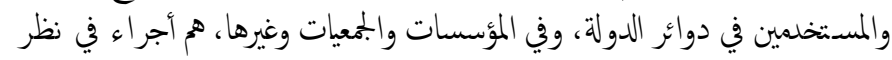

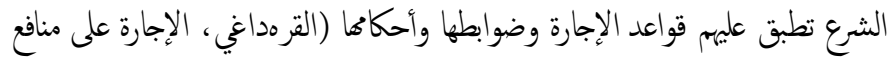

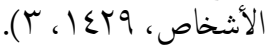

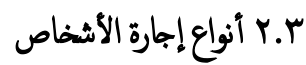

قسم العلماء إجارة الأشخاص على نوعين، وها:

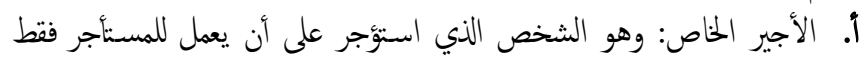

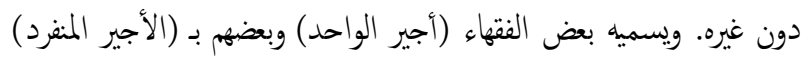

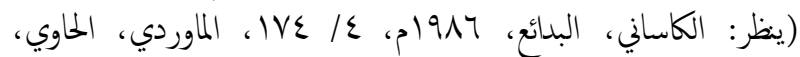

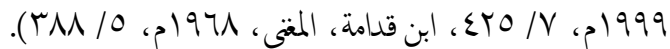

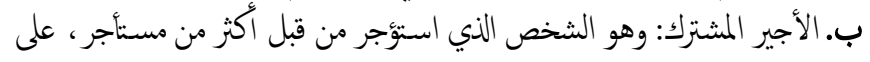

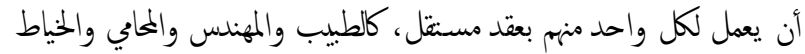

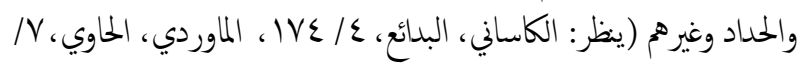

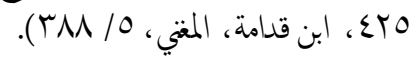

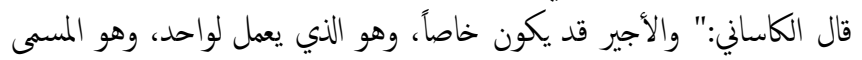

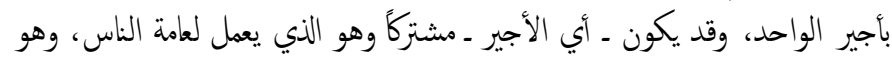

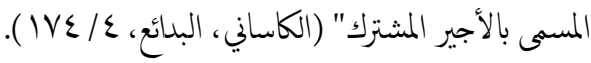

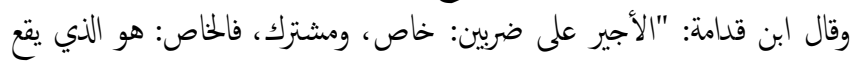

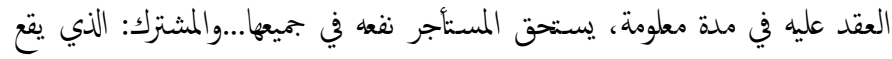

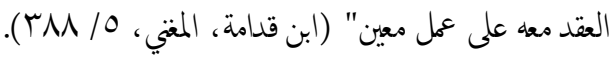

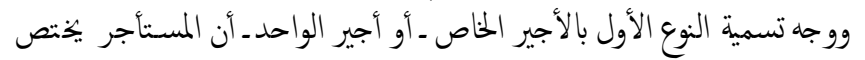

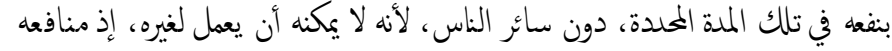

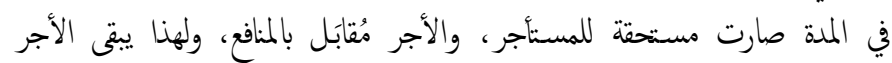

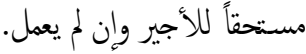

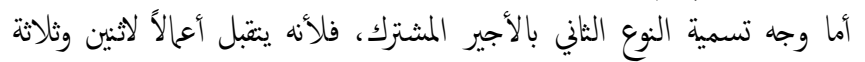

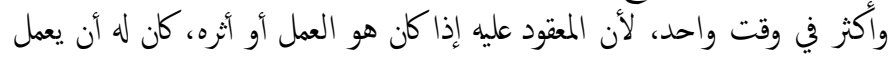

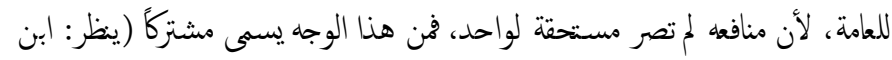

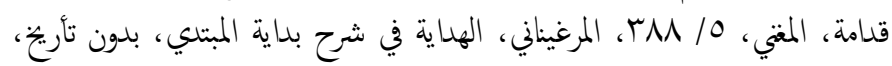

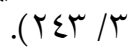

ص/N/1)، ورتب الشيءُ رتوباً إذا انتصب، فإنما هو راتب (الأزهري، تهذيب اللغة،

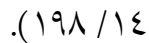

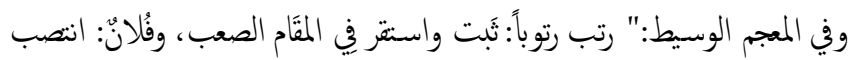

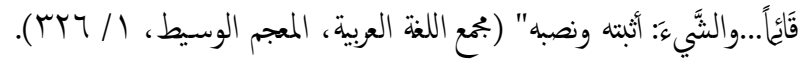

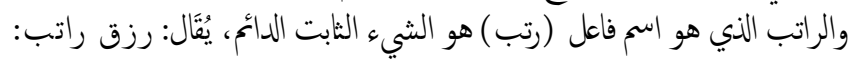

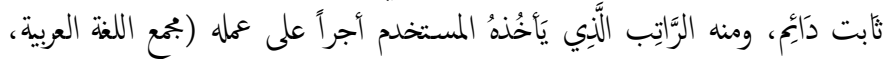

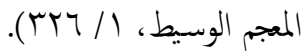

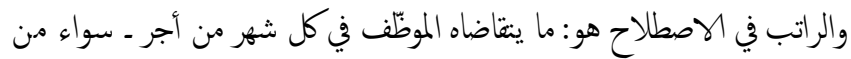

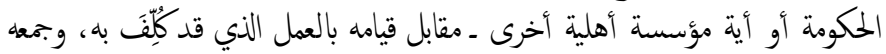

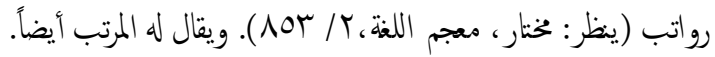

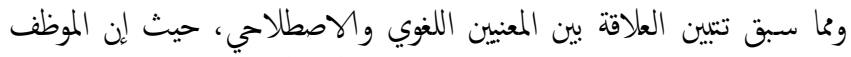

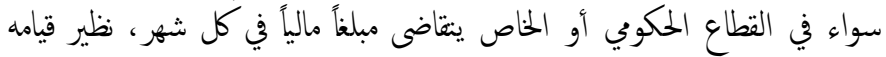

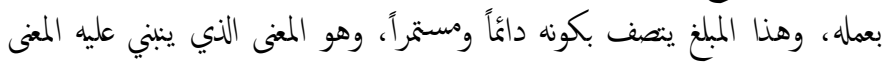
اللغوي. هنا، والراتب أو المرتَّب كلمة مستحاثة، لم يستخدما الفتهاء القامى، وإنما كانوا

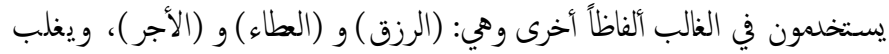

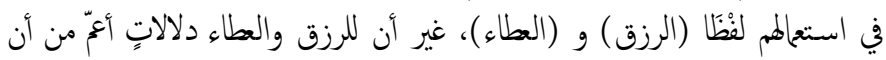

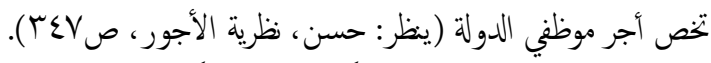

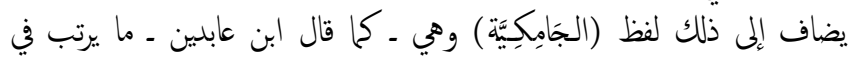

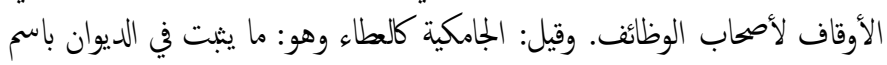

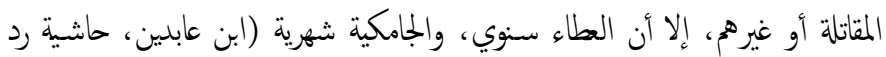

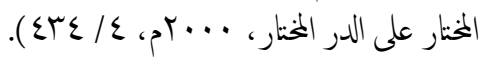

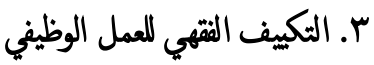

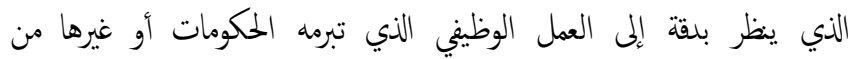

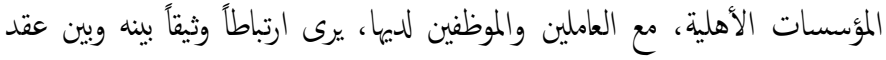

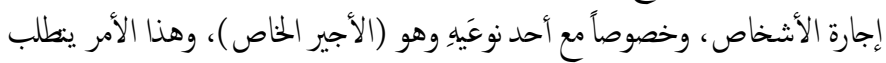
منا بيان إجارة الأشخاص من حيث النعريف والأنواع والمشروعية.

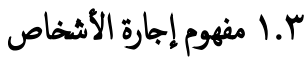

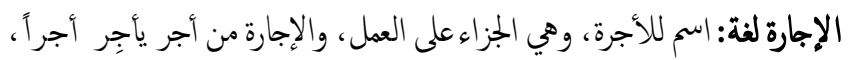

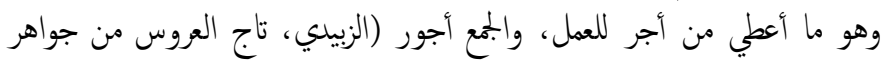

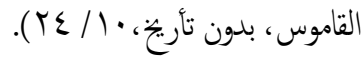
والإجارة في تعريف الفقهاء هي: عقد على منفعة معلومة بعوض معلوم، (ينظر:

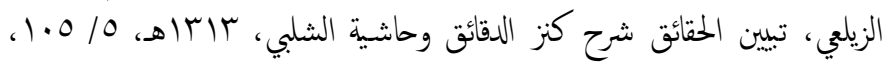

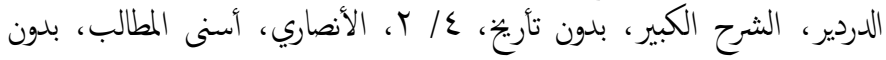

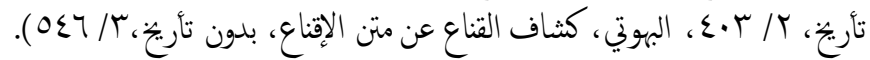

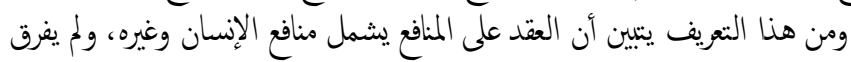

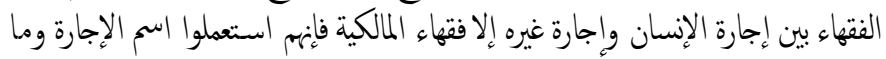

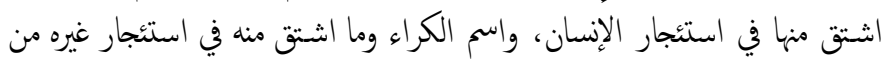

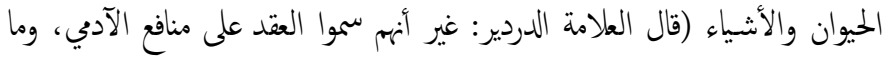

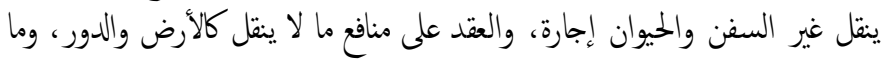


نفسه، ولا يستحقه النائب؛ لأنه استيفاء للمنفعة بلا عقد، لتعين المققود عليه

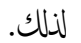
أما الأجير المشترك فيجوز له ـ إذا لم يشترط عليه العمل بنفسه ـ تكليف غيره

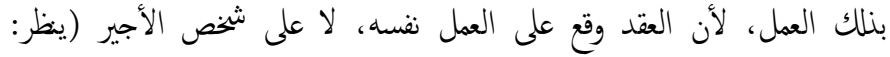

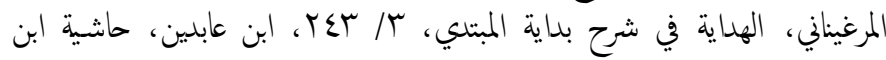

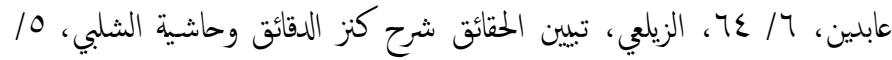

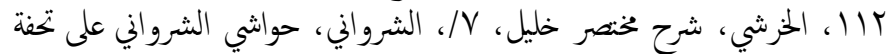

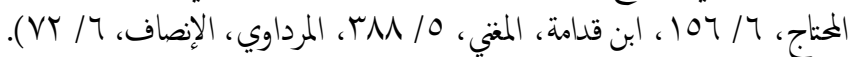

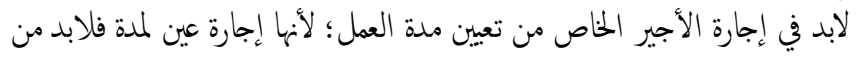

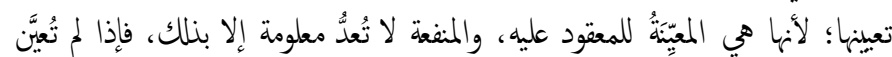

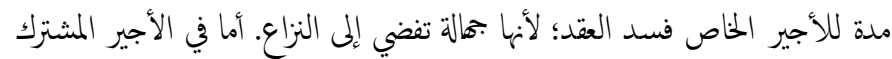

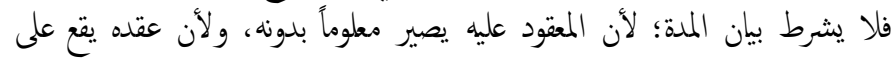

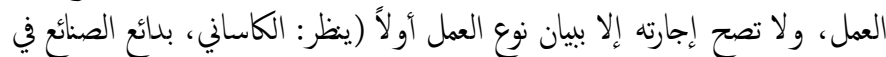

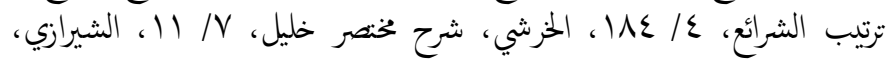

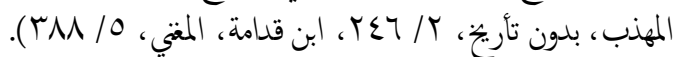

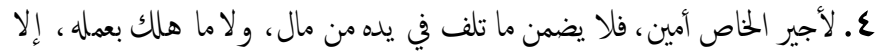

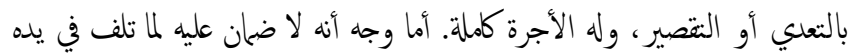

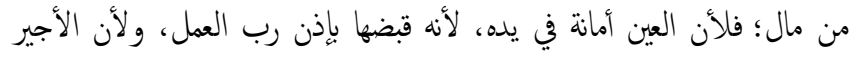

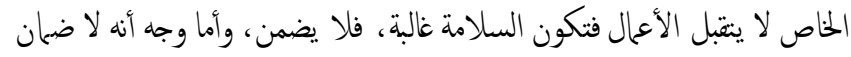

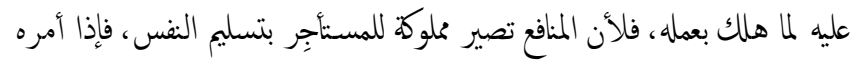

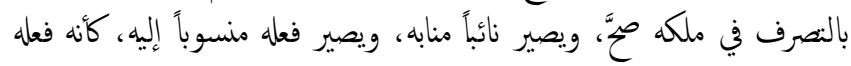

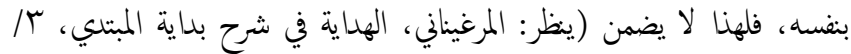

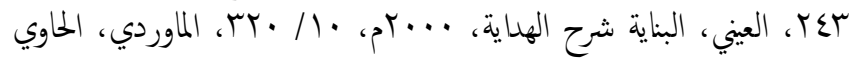

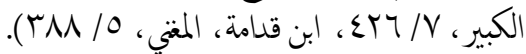

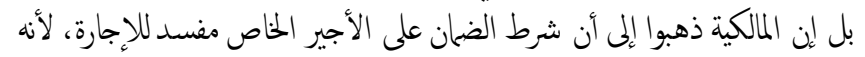

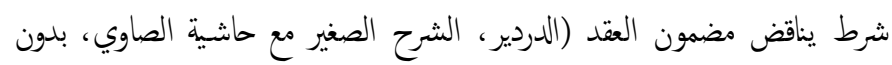

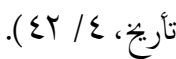
وذهب بعض الشافعية إلى أن الأجير الخاص يضمن كالأجير المشترك، صيانة

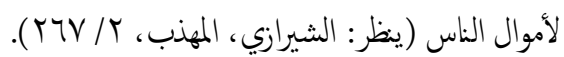

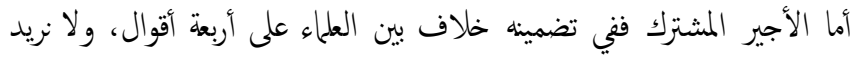

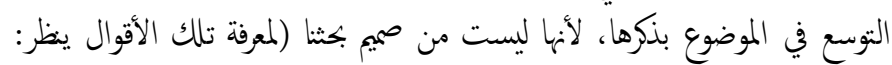

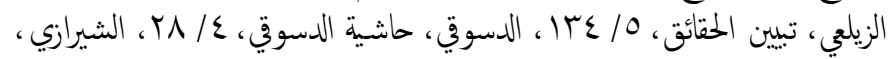

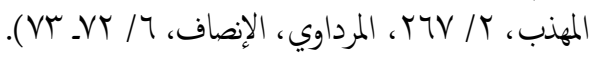

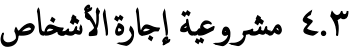

ثبتت مشروعية هنا النوع من الإجازات بنص الكناب والسنة وإجاع أهل العلم.

أولأ: الكناب

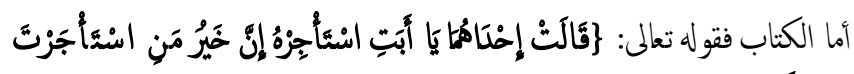

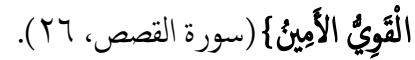

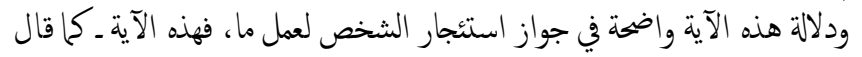

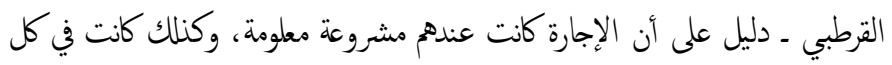

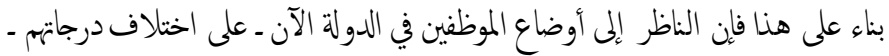

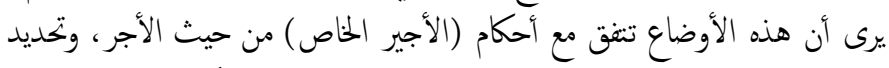

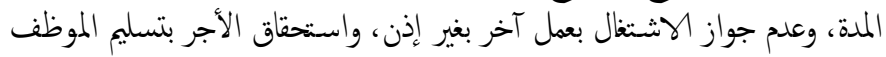

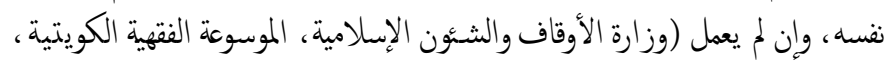

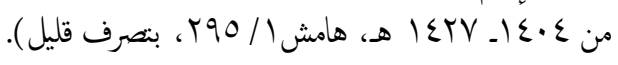
r.r الفرق بين الأجير الخاص والأير المشترك

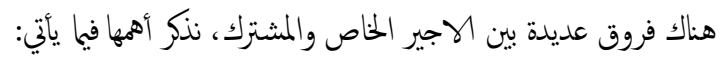

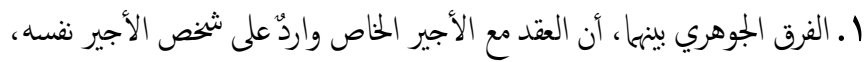

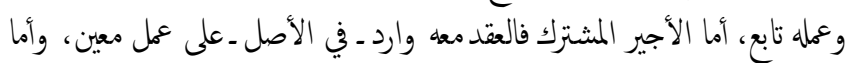
تسليم نقسه فتابع له. وعلى هذا فلو قام الأجير الخاص بتسليم نفسه في تلك الماك المدة المعلومة، وبتي في عمله

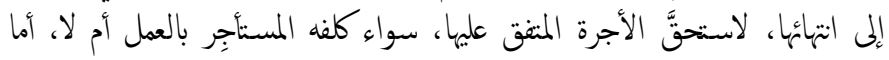

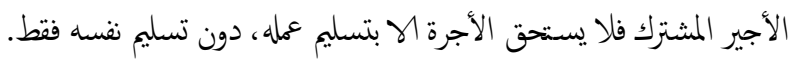

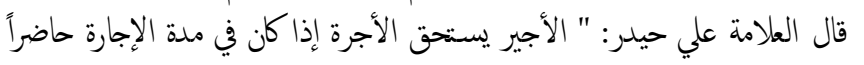

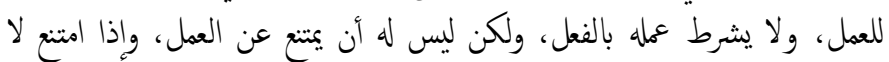

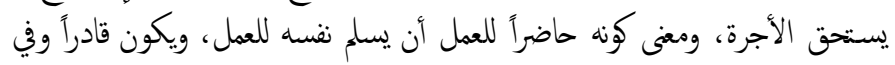

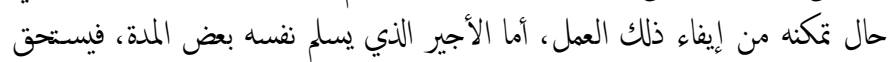

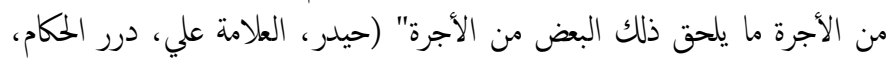

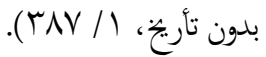
وإنما لا يشترط عمل الأجير الخاص بالفعل، لأنه لماكانت منافع الأجير مدة الإجارة

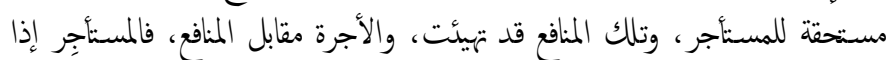

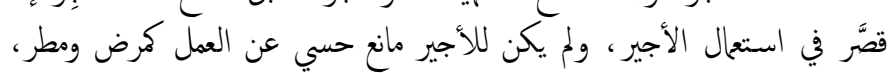

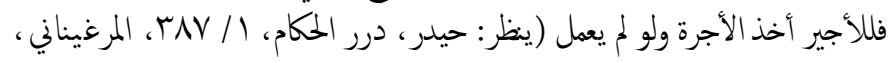

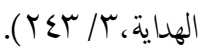

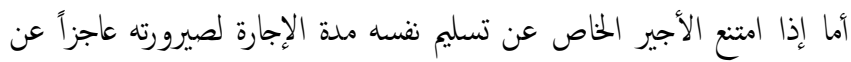

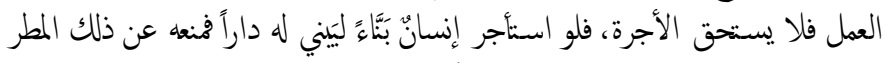

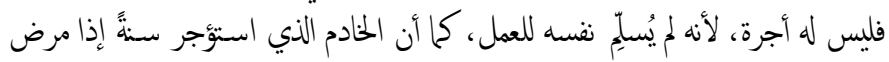

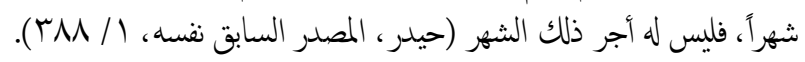

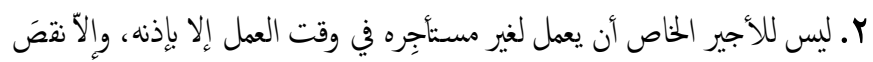

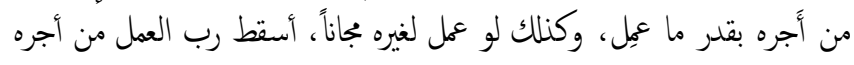

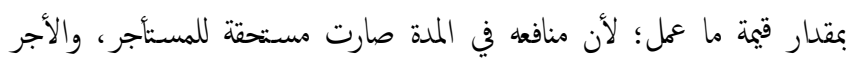
مقابل بالمنافع، ولهذا يبقى الأجر مستحقاً وإن نُقِضَ العملُ.

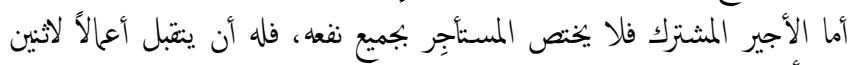

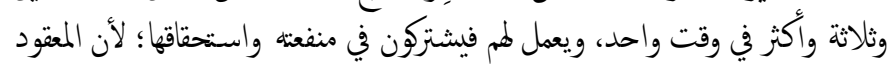

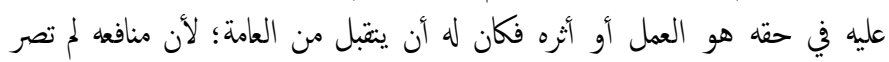

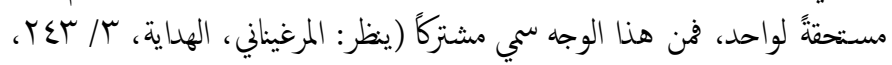

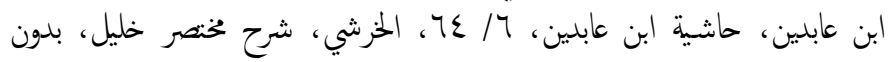

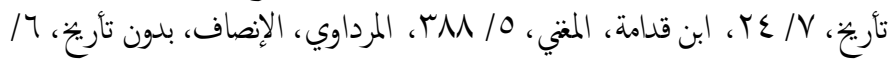
. ( VT

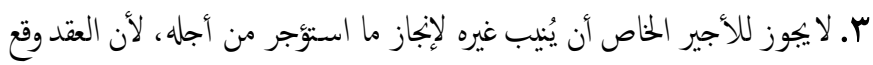

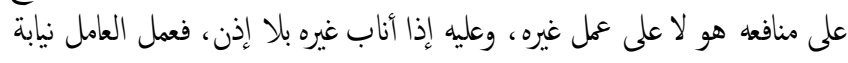

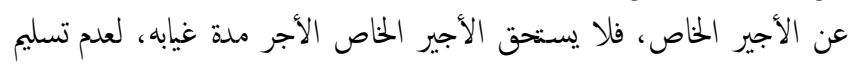


عنهم) إلى يومنا هذا من غير نكير، فلا يُعباً بخلافه، إذ هو خلاف الإجحاع"

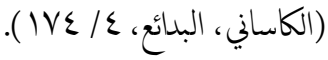

\section{ع. حكم غياب الموظف (الأجير الخاص)عن الممل وأسبابه}

يختلف حكم غياب الموظف (الأجير الخاص) بسبب اختلاف طبيعة الغياب

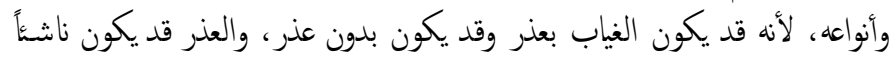

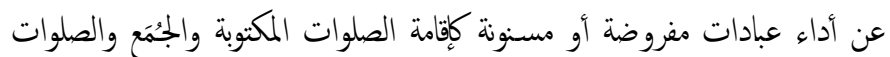

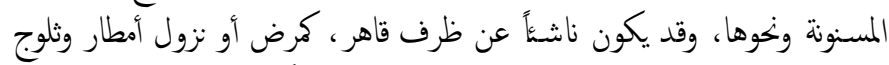
ونخو ذلك. وهنا ينطلب أن نخصص لكل جزئية منها نها مطلبًاً على حدة.

\section{ع.ا غياب الموظف عن الممل بدون عذر شرعي وأثره في استحقاق الراتب} قلنا - فيما سبق - أن عقد الوظيفة ينطبق عليه عقد الإجارة وأحكامه وضوابطه،

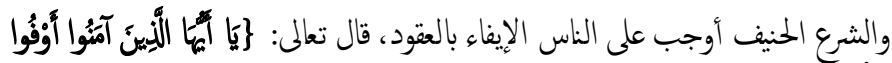

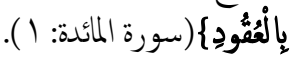

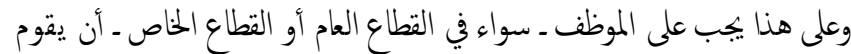

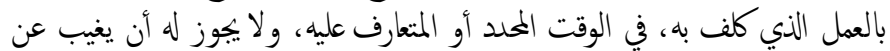

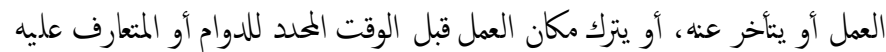

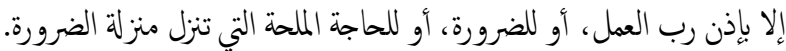

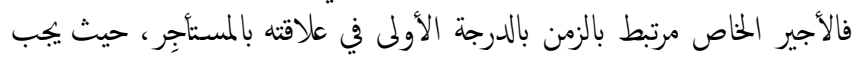
عليه الالتزام بالوقت، فالموظف أو العامل الذي حدد له اله وقت ـ من الساعة الثامنة

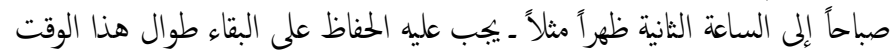

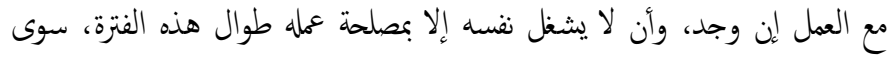

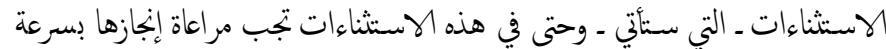

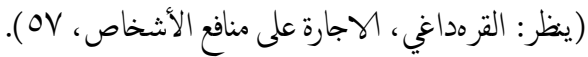

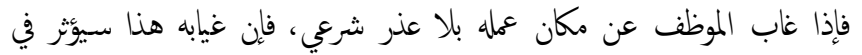

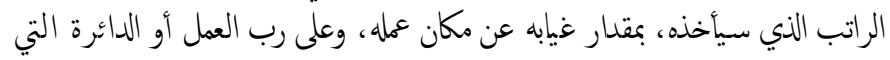

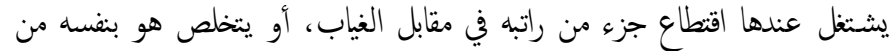

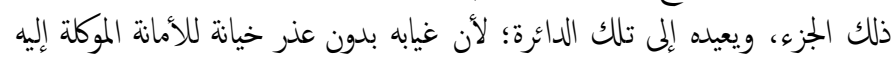

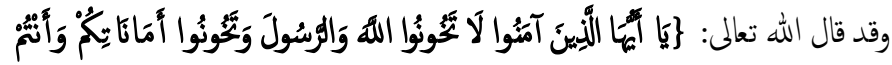

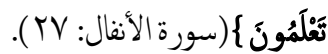

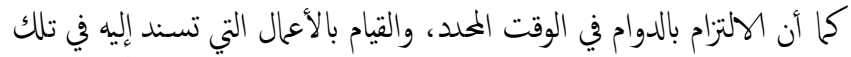

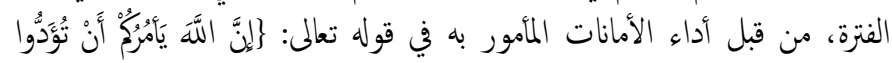

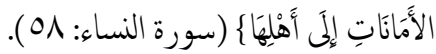

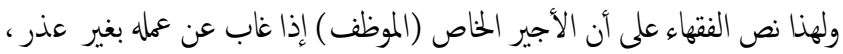
سقط من أجره قسط غيابه.

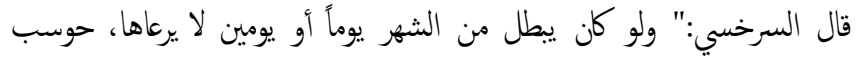

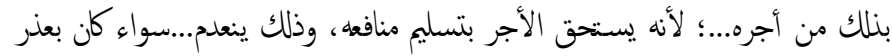

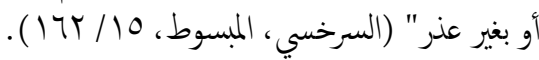

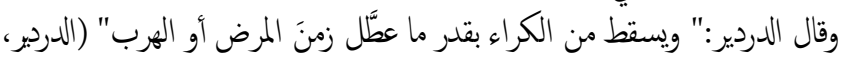

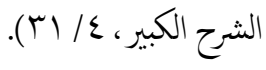

ملة، وهي من ضرورة الخليقة، ومصلحة الخلطة بين الناس (القرطبي، الجامع لأحكام

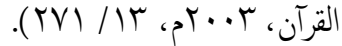

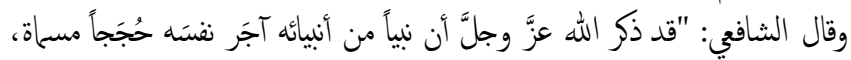

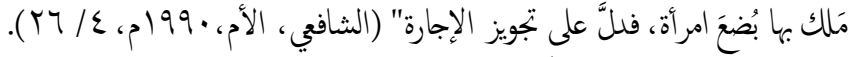

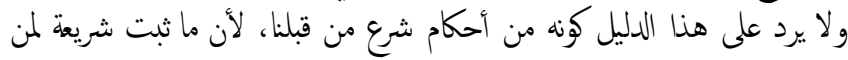

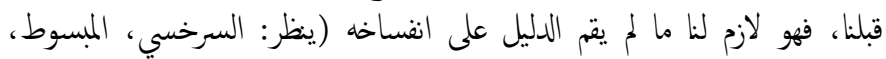

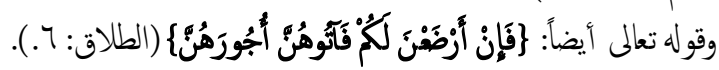

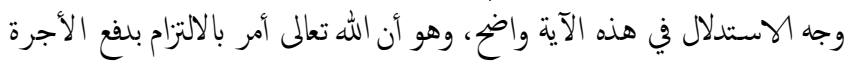

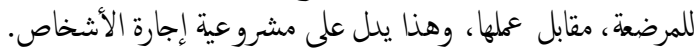

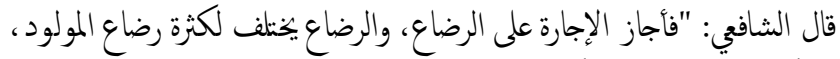

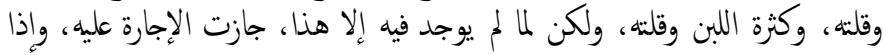

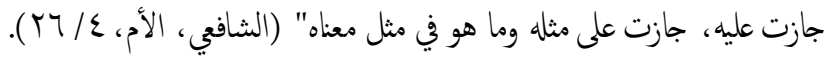
ثانيا: السنة

أما السنة فأحاديث كثيرة منها: ما رواه ابن ماجة من حديث ابن عمر (رضي الله

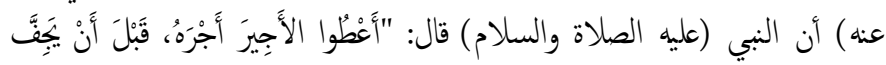

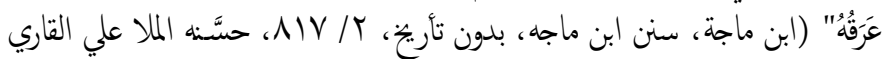

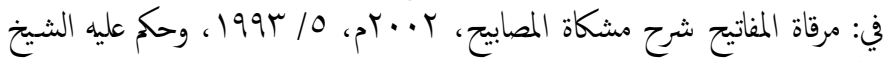

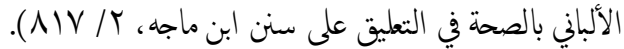

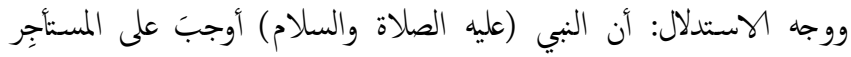

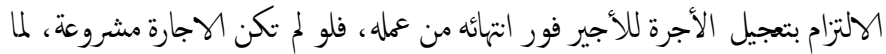

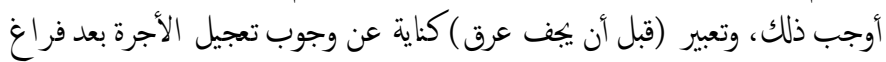

ثالثا: الإجاع

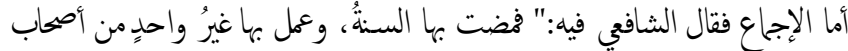

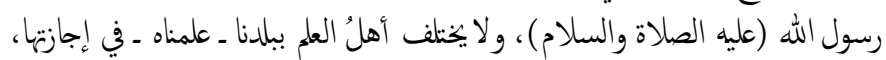

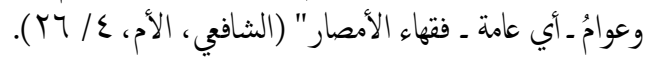

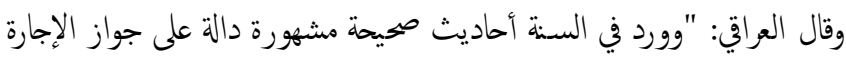

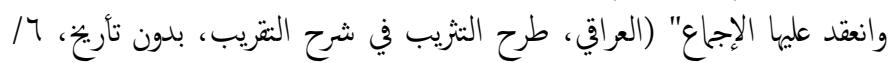
.( IV

وقال ابن قلامة: "يجوز استئجار الآدمي، بغير خلاف بين أهل العلم" (ابن قلامة،

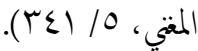

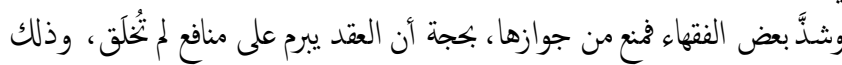

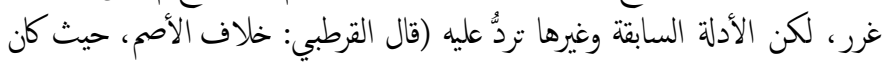

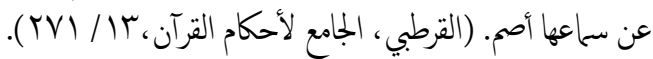

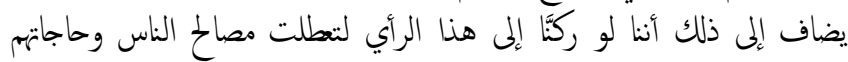

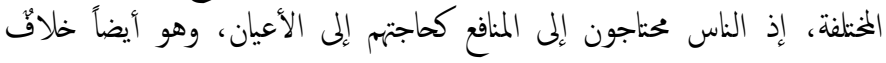

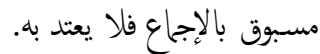

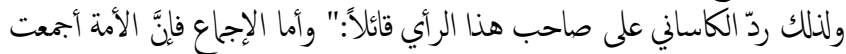

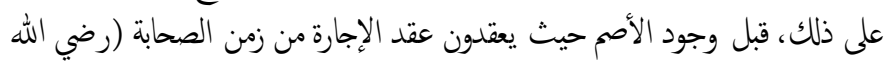


ب. الشافعية: قال ابن حجر: "يستثنى من زمن الإجارة فعل المكتوبة... وطهارتها

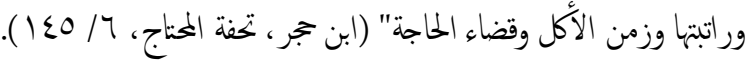

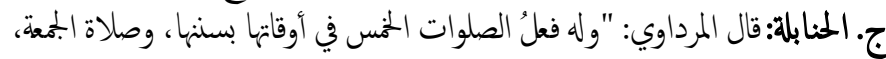

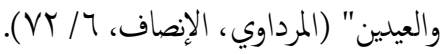

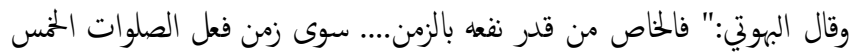

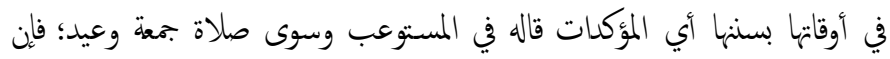

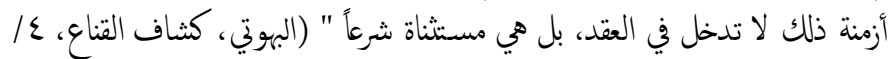

.$(r t$

أما المالكية فلم أقف في كتبه على نص فيا يتعلق بهذه الجزئية.

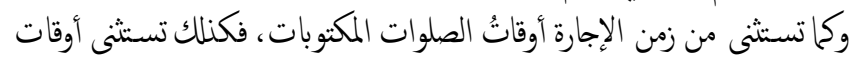

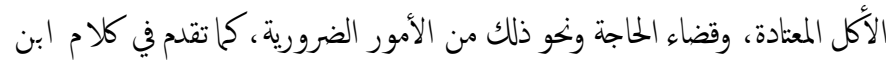

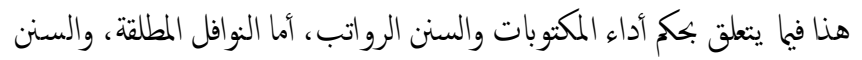

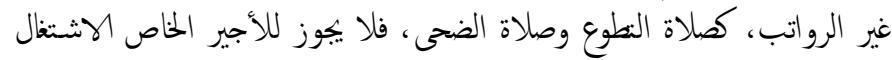
عها، في فترة عمله.

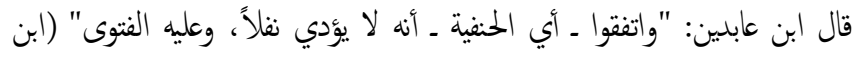

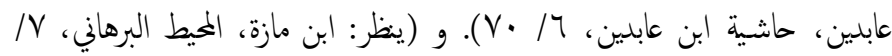
.( $\Sigma$ ). وقال نصير الدين السامري: "ولا ينطوع بعد أداء الفرض إلا بالسنن المؤكدات"

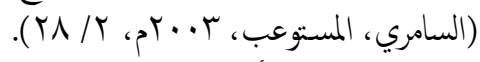

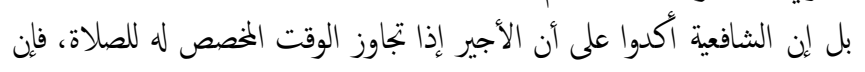

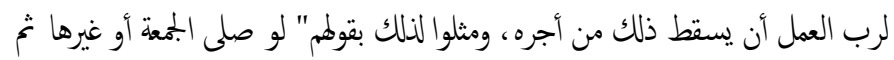

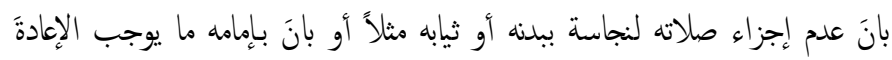

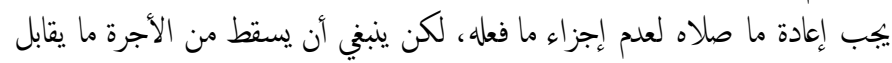

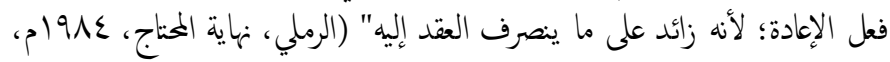

. (YNT/O

وأكدوا أيضاً على أنه يجب على الأجير أن يقتصر في أداء الصلاة على أقل الكمال

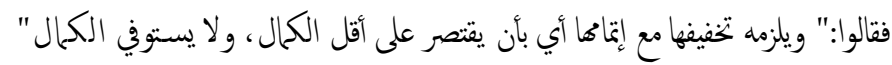

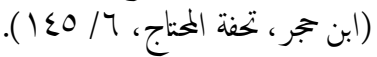

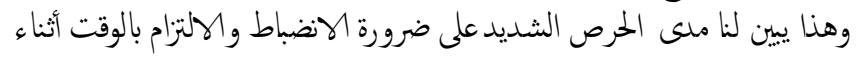
الدوام الرسي، بحسب ما اتفق عليه الطرفان، أو ما تعارف عليه أهل البلد.

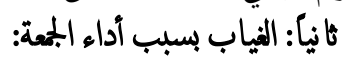

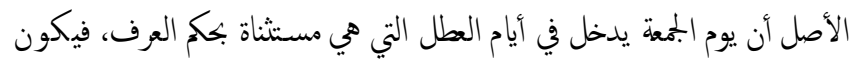

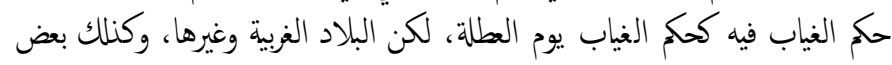

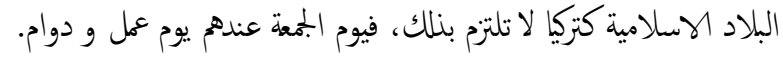

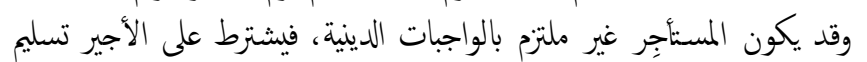

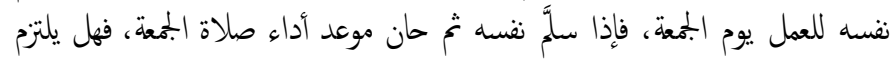

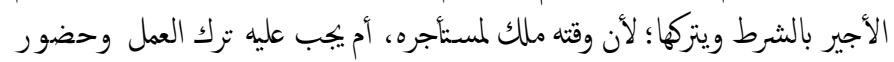

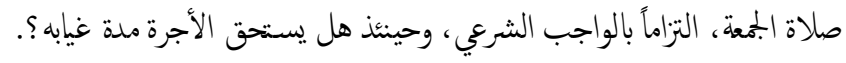

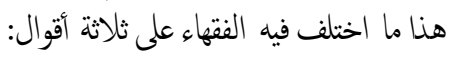

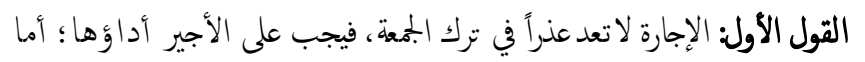

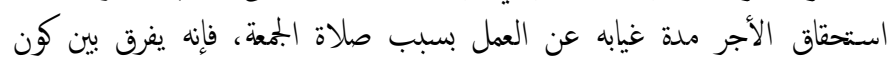

ونقل الشربيني عن الدمبري قوله:" كان الشيخ تقي الدين القشيري إذا بطَّل يوماً

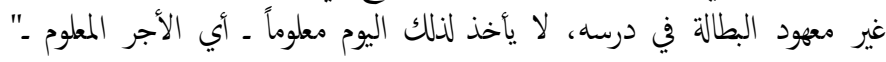

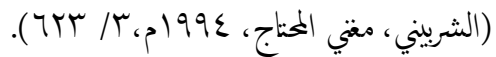

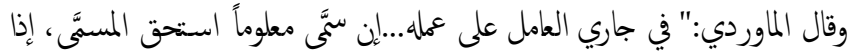

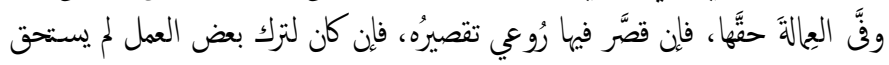

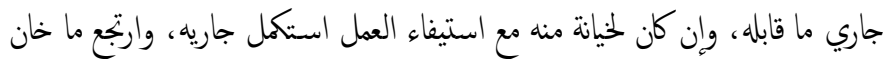

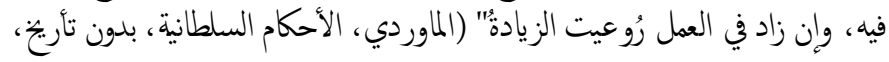

. (rIT

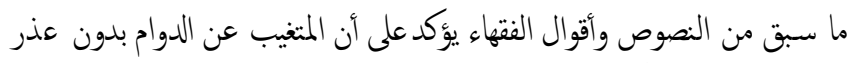

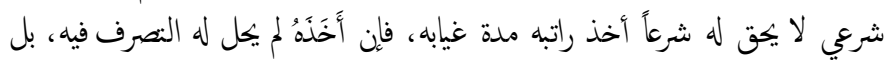
عليه إعادته إلى دائرته التي يعمل فيها.

\section{ع. غياب الموظف عن الممل بعذر شري وأثره في استحقاق الراتب}

شرط استحقاق الموظف (الأجير الخاص) للأجرة هو تسليم نقسه واستعداده

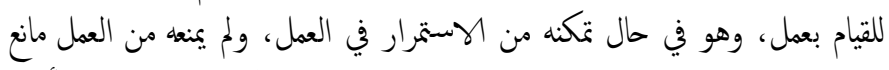

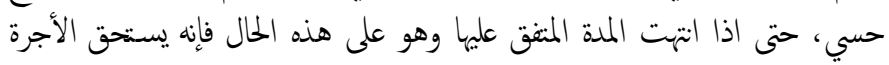

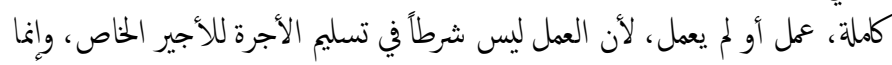

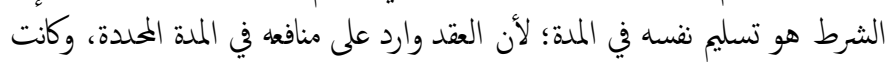

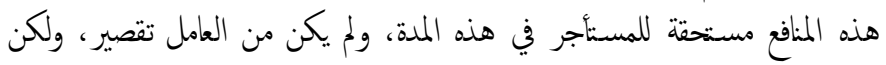

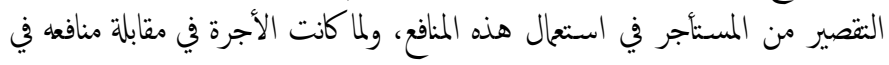

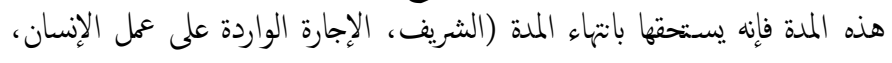

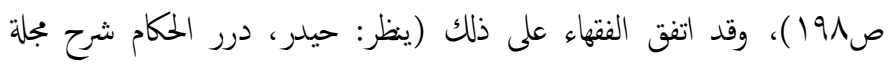

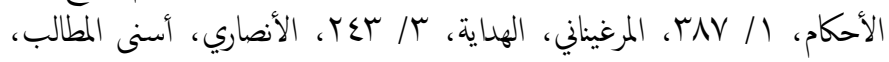

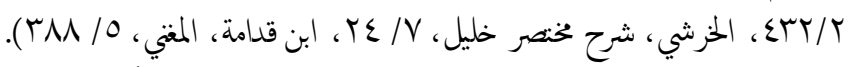

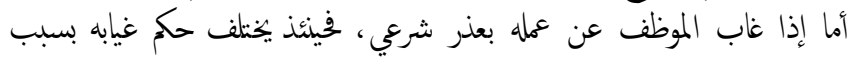

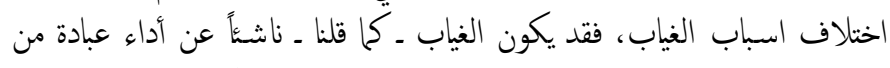

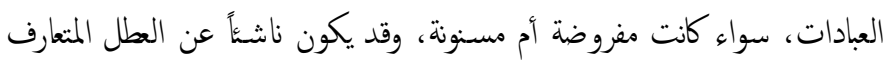

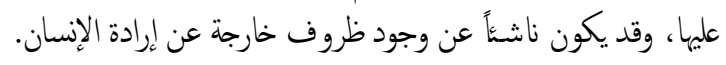
ولذلك سنخصص لكل واحدة منها فرعاً على حدة:

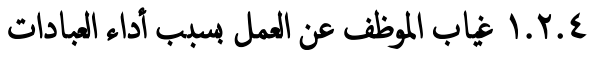

\section{أولاً: الفياب بسبب أداء الصلوات المكتوبة مع رواتهها:}

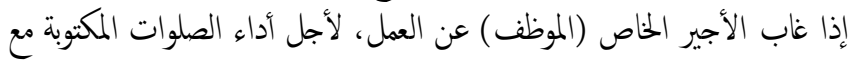

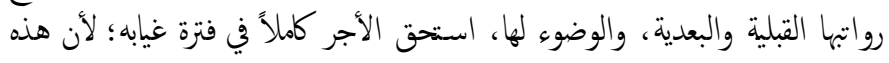

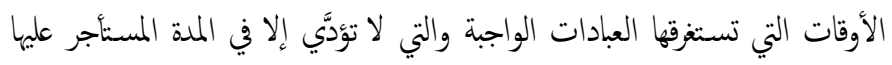

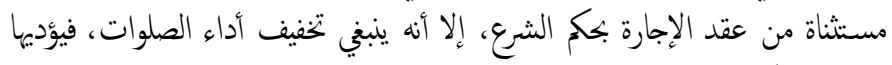

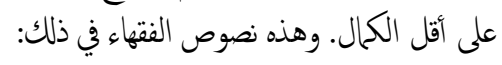

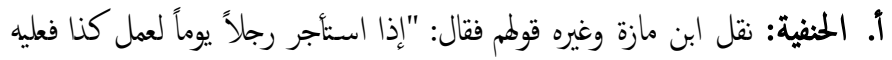

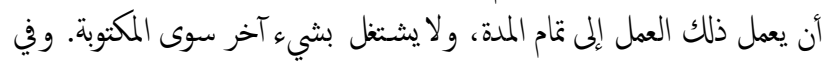

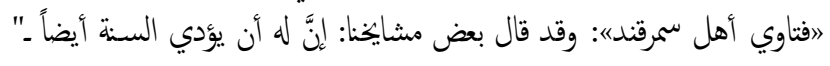

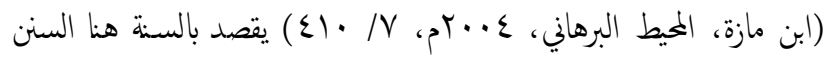
الرواتب؛ لأن النوافل لاتؤدى كما سيأتي. 
تقديراً للحاجة وتحقيقاً للمصلحة، وبهذا صدر قرار من المجلس الأوروبي للإفتاء

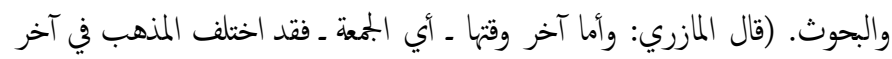

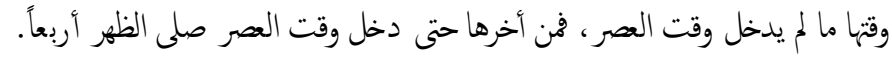

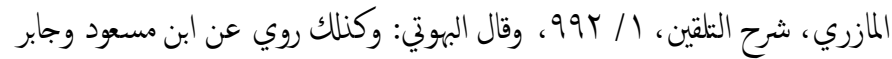

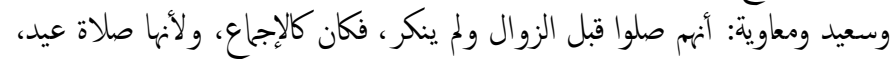

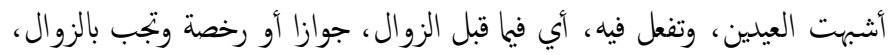

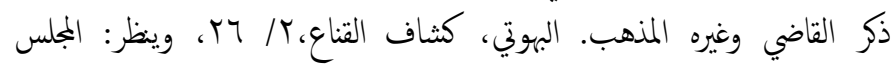

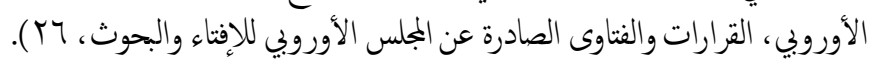

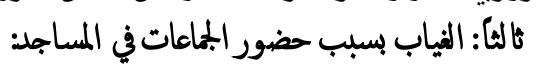

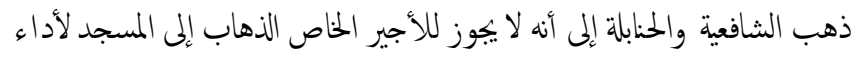

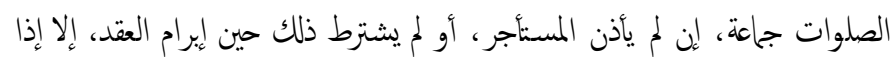

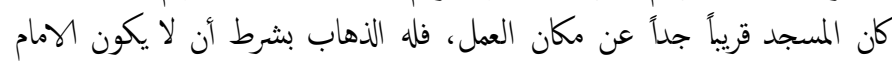

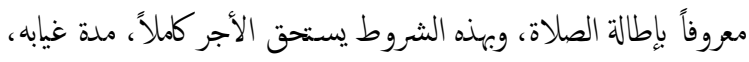

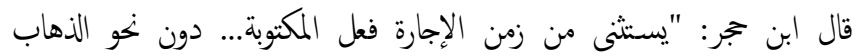

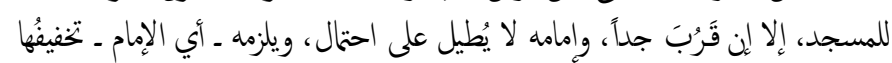

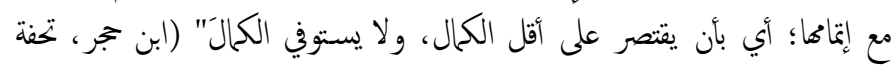

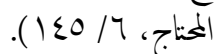

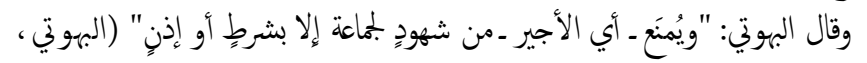

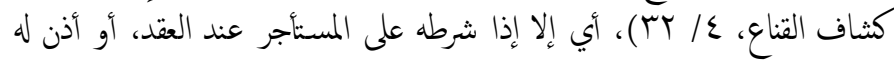
المستأجر. وقيَّد بعض الشافعية جواز الذهاب إلى المسجد بما إذا كان قُربْ المسجد مساو

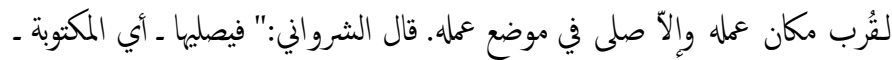

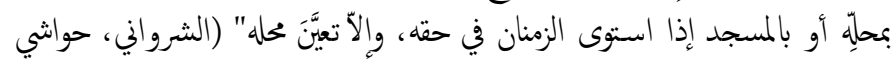

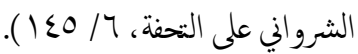

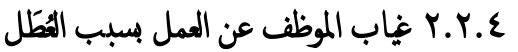

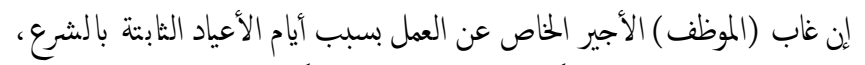

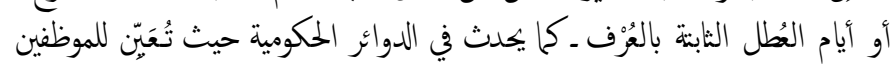

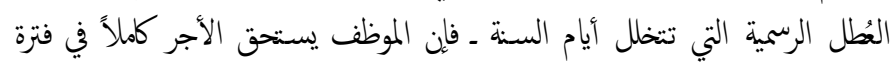

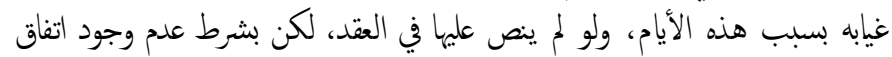

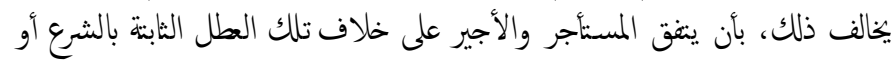

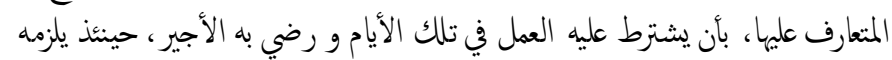

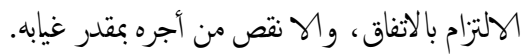
وهذه نصوص الفقهاء في ذلك:

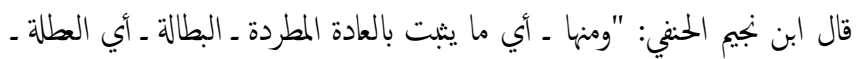

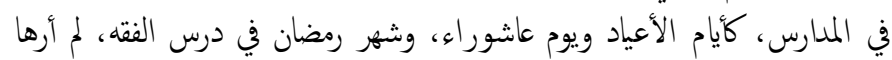

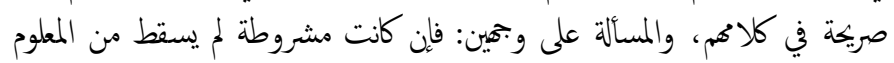

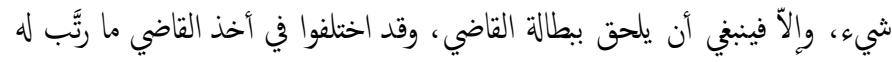

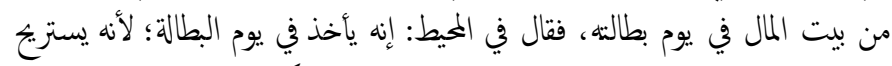

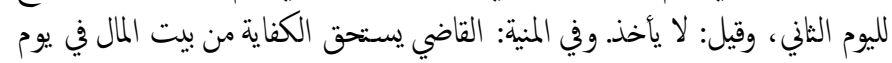

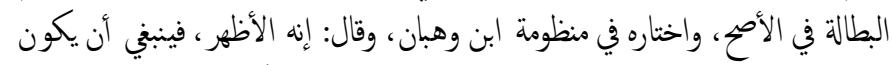

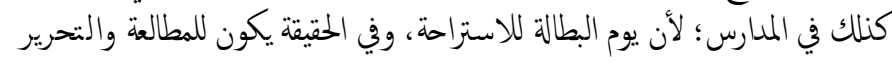

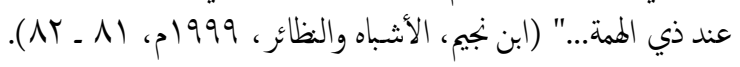

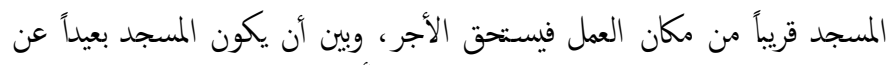

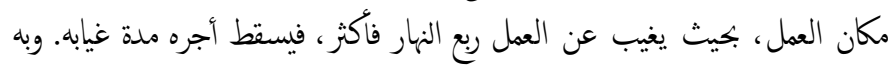
قالت الحنفية.

نقل ابن عابدين عنه فقال:" لا يُمنع ـ أي الأجير - في المصر من إنيان المجعة، إنهان

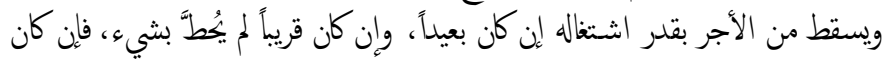

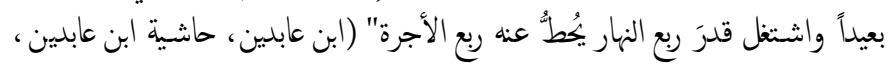
. ( V . / T

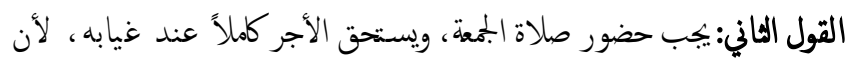

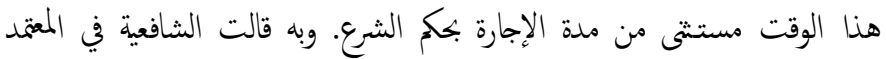
والحنابالة. قال النووي: "استأجره لعملٍ مدةً، يكون زمن الطهارة والصلوات، فرائضها وسنها

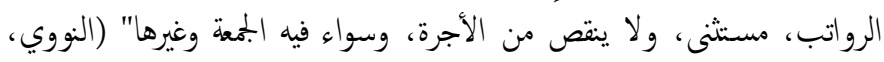

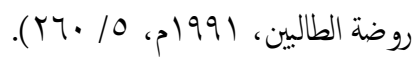

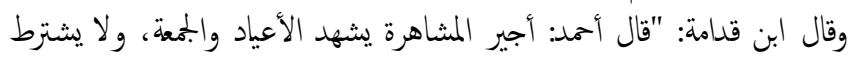

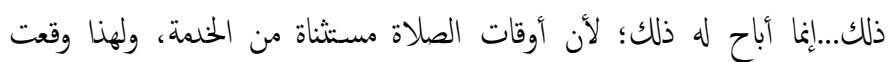

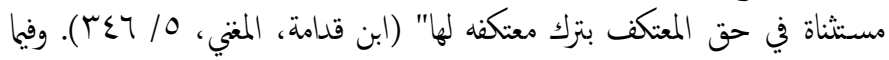
سبق آنفاً نقلنا عن البهوتي مثل ذلك.

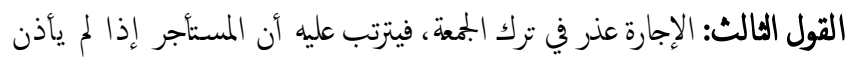

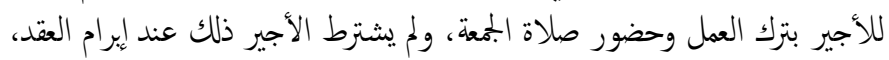
سقط أجره مدة غيابه. وهو قول عند الشافعية.

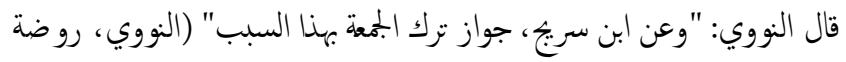

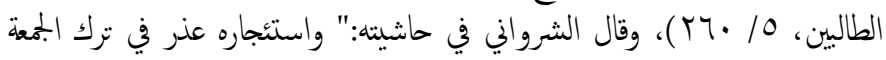

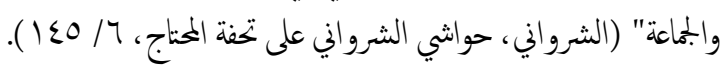

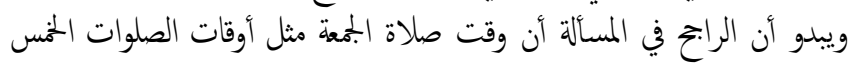

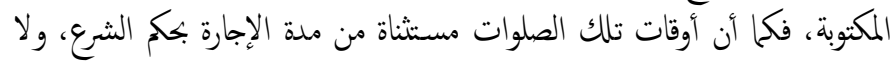

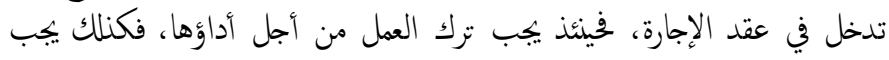

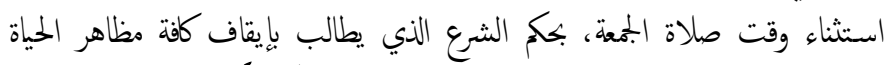

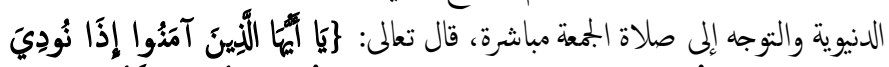

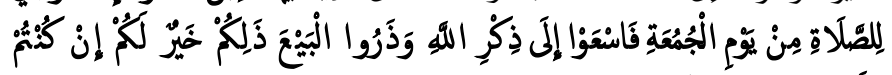
تَنْلَمُونَ \{(سورة المجمعة: 9 ).

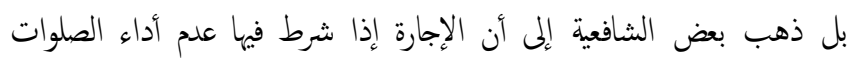

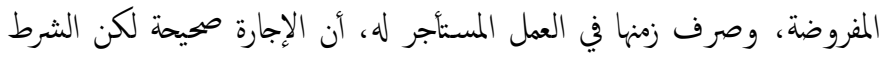

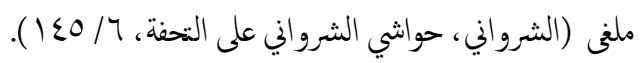

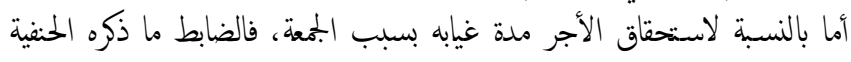

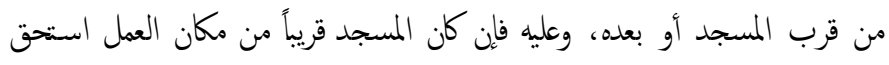

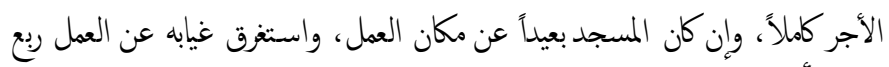

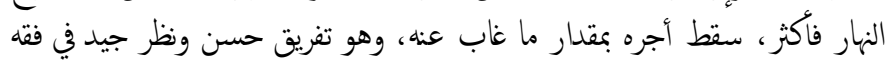

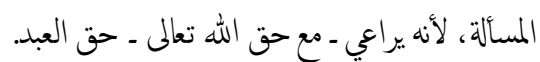

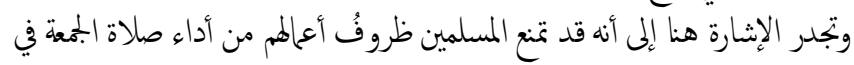

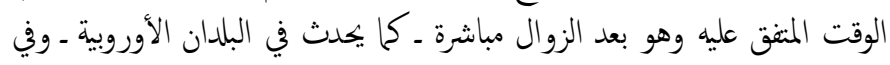

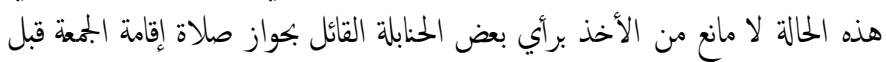

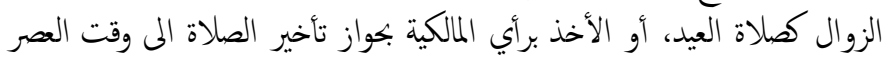


بالموت. ثم قال: ومتى انفسخ العقد...بتعذر المنغعة بعد استيفاء بعض المنفعة قسم المبر

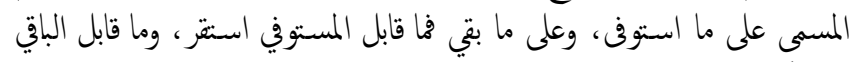

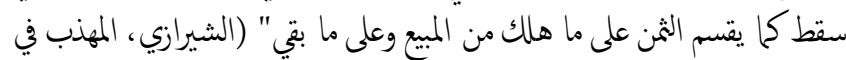

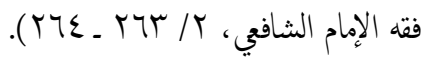

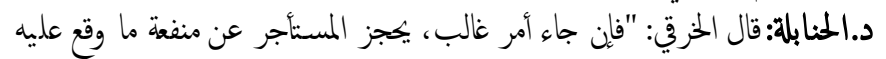

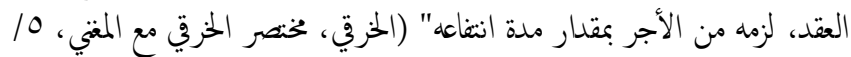

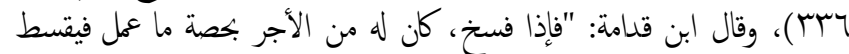

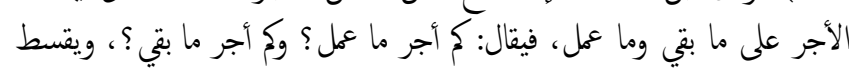

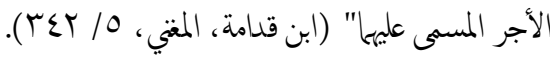

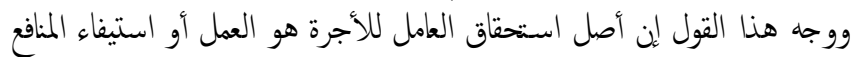

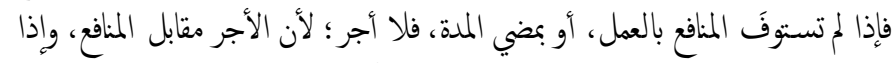

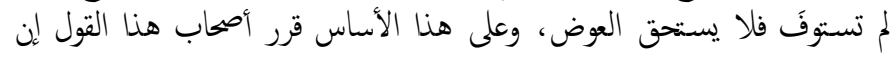

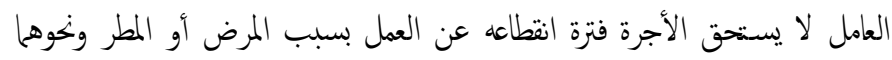

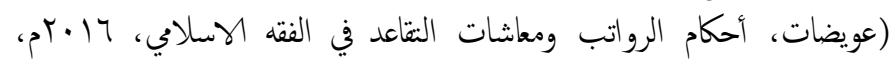
صمشس، بنصرف).

قال الكاساني في تعليل هذا القول:" لأن المعقود عليه المنغعة في تلك المدة؛؛ لأنها

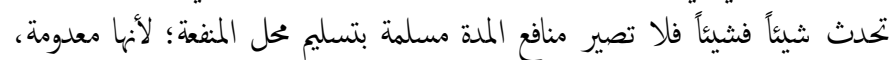

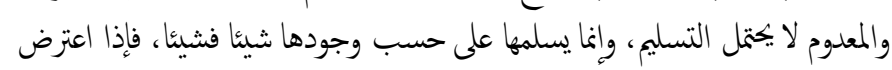

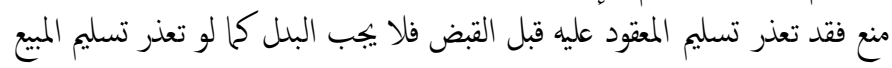

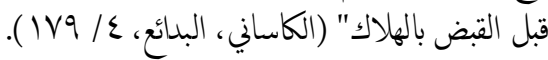

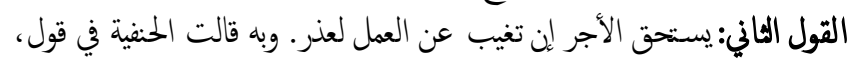

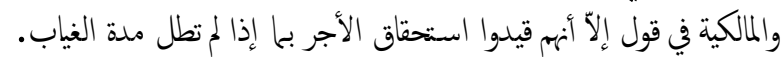

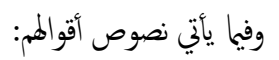

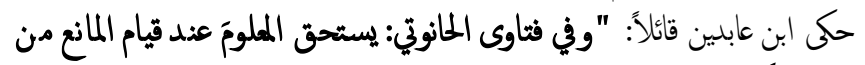

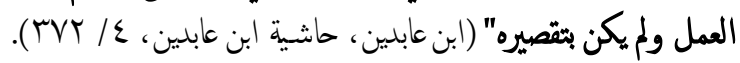

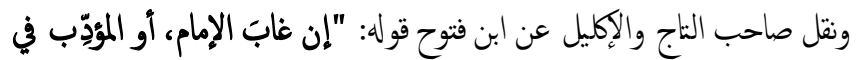

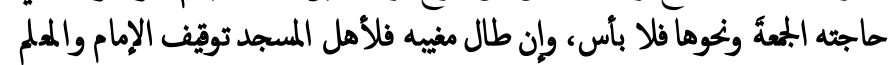

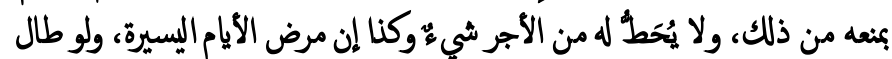

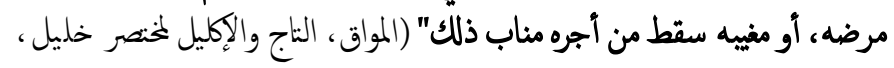

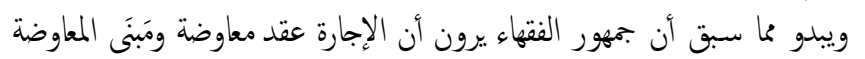

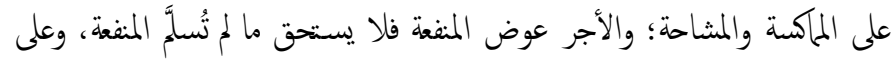

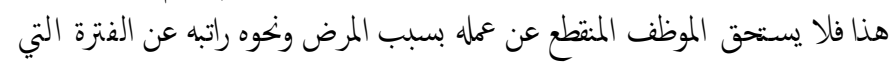

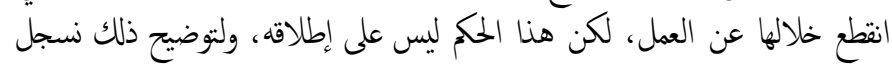
هذه النقاط:

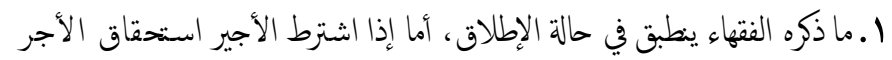

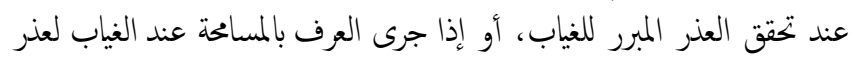

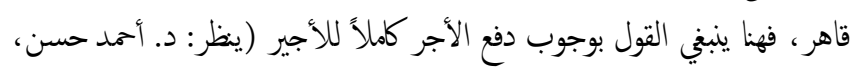

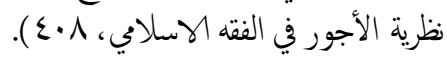

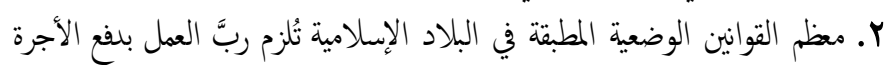

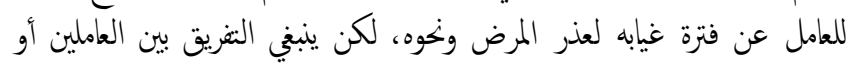
الموظفين في القطاع العام والقطاع الخاص.
وقال ابن مازة: "ولم ينقل عن محمد ـ رحمه الله ـ أن القاضي هل يأخذ الرزق في

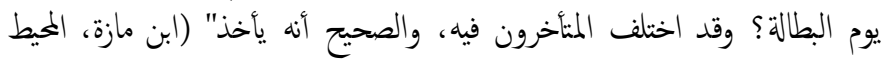

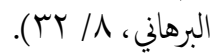

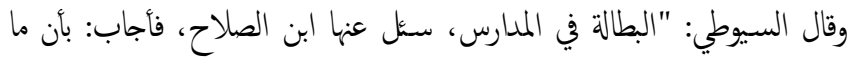

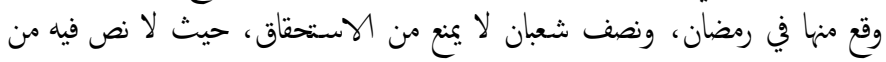

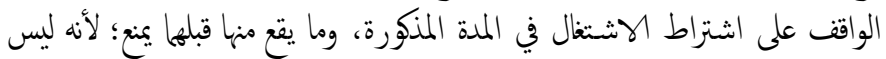

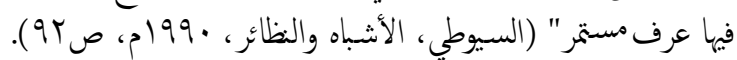

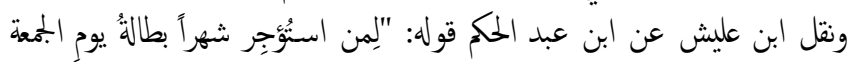

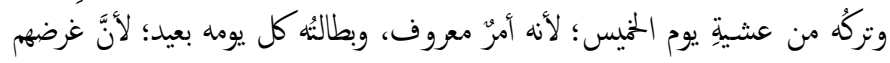

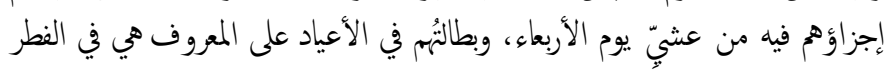

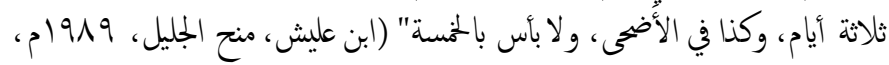

. ( $\Sigma \Lambda T / V$

بل نصَّ بعض الفقهاء على السحاح للأجراء من أهل الذمة الغياب عن العمل أيام عطلهم التي اعثادوا ترك العمل فيها.

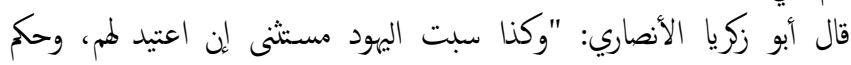

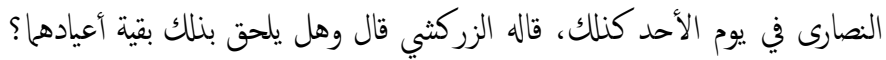

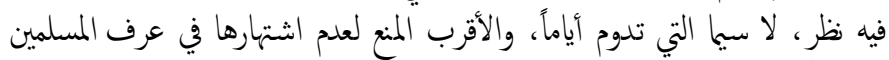

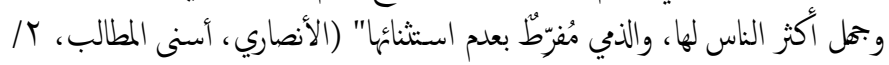

דr

\section{ع. ع. غياب الموظف عن الممل بسبب ظرف قاهر}

تمتد عقود العمل في زماننا شهوراً وسنوات، وقد تستمر إلى سن النقاعد، فإذإِ

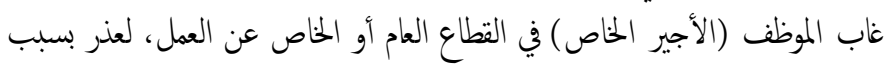

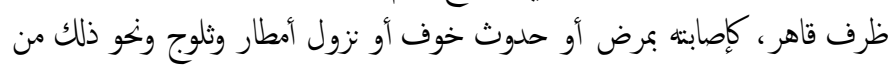

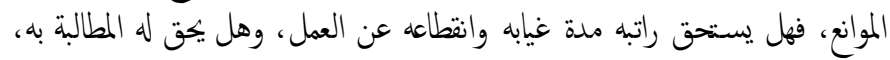

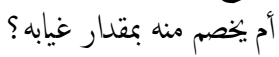
هنا ما حصل فيه اختلاف بين الفقهاء على قولين:

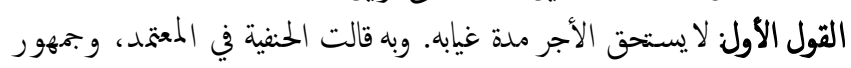

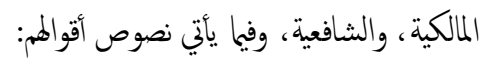

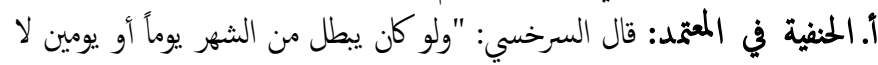

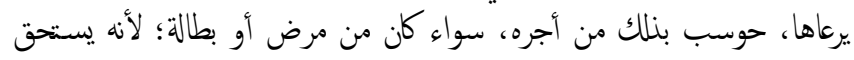

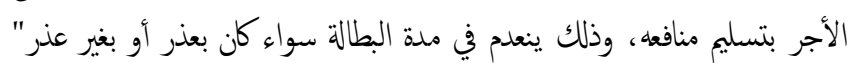

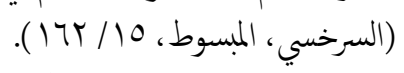

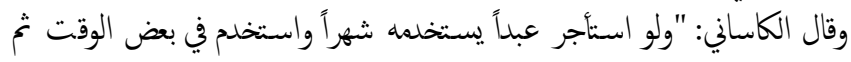
حدث مانع ينع من الاننغاع من مرض أو إباق لا تلزمه أجرة تلك أك المدة" (الكاساني،

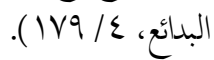
وقال الزيلعي: "فيستحقه ـ أي الأجير الخاص ـ ما لم يمنهه من العمل مانع حسي

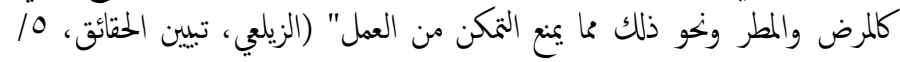
(ITV

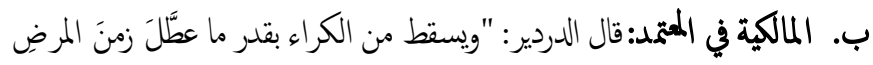

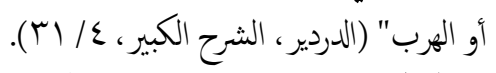

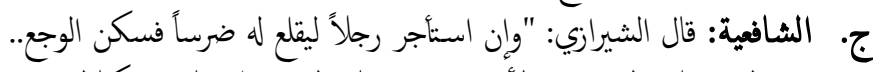

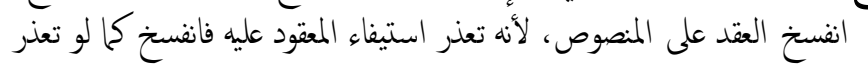


Y. إجارة منافع الأشخاص نوعان: إما إجارة شخص ينحصر عمله لمستأجره ولا يعمل

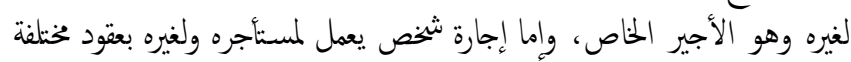

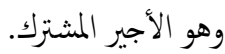

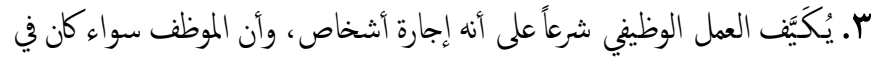

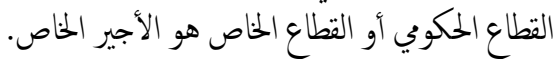

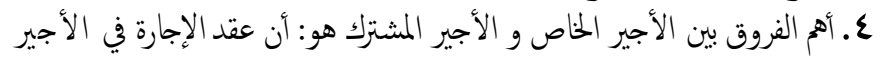

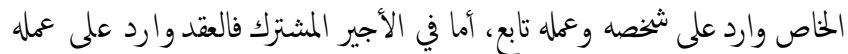

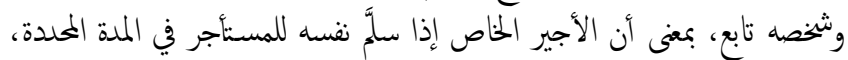

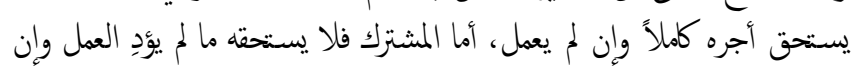
سلّل نقسه.

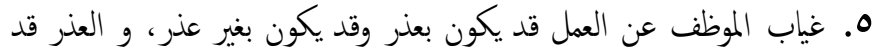

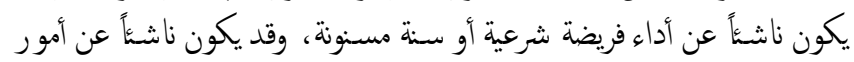

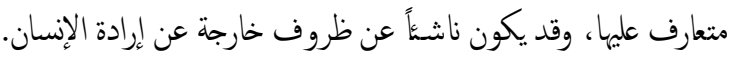

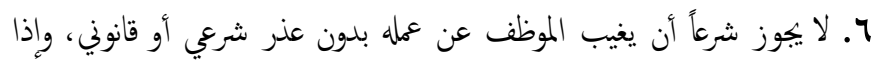

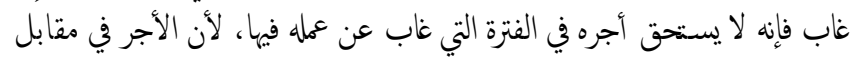
تسليم نفسه لمستأجره في تلك الفترة المحلدة، وهو لم يفعل ذلك الك.

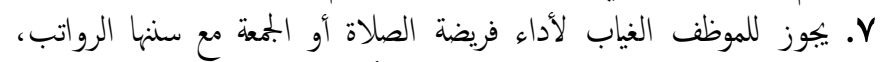

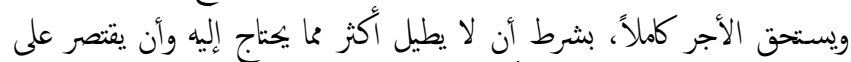

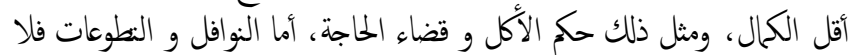
يجيوز شرعاً الاشتغال بها في فترة الدوام. 1. يجوز للموظف الغياب من أجل أيام الططل الثابتة بالشرع أو المتعارف عليها، ويستحق أجره كاملاً.

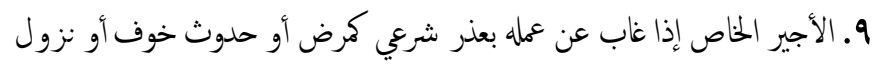

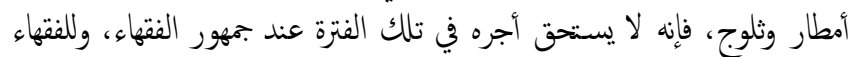

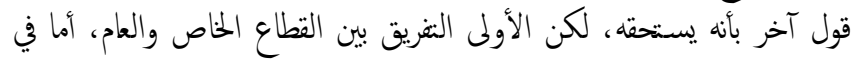

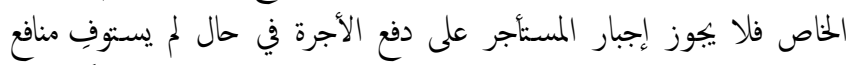

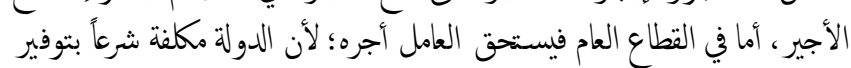

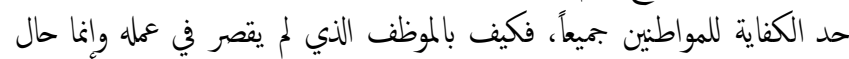
دون حضوره ظرف خارج عن سيطرته.

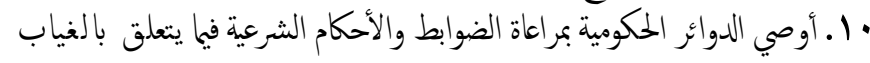

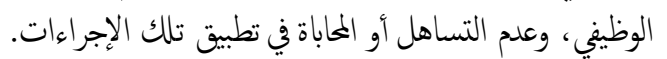

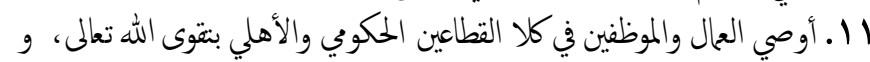

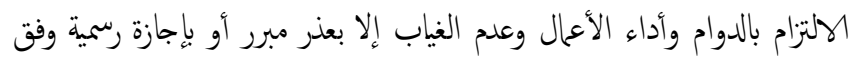

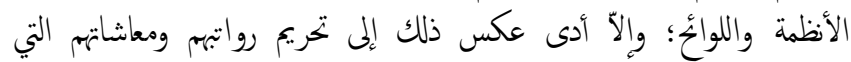
يستلمونها بمقار غياهه.

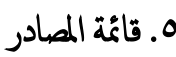

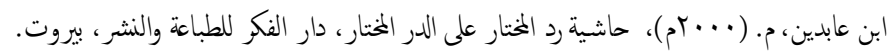

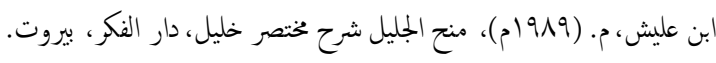

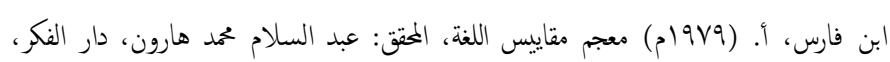

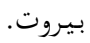
ابن قدامة، ع. (1971)م)، المغني، مكتبة القاهرة، القاهرة.

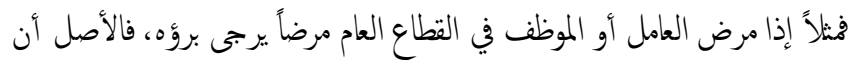

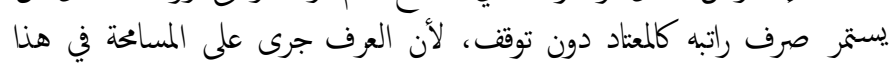

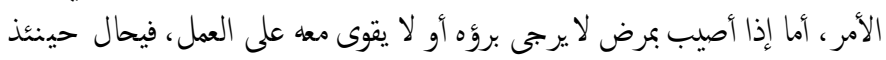

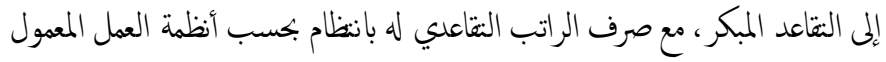

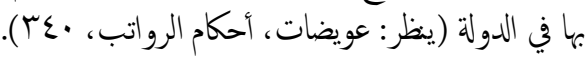

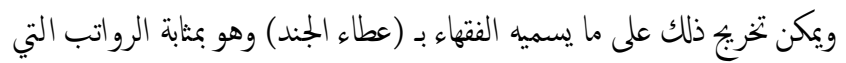

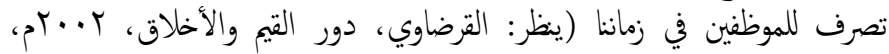

.$(199$

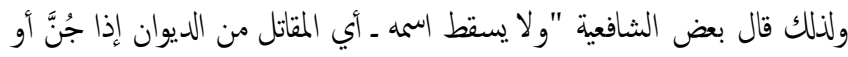

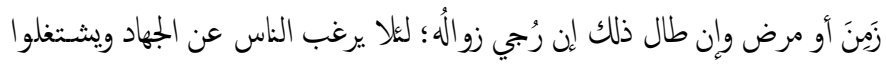

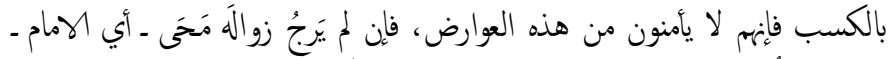

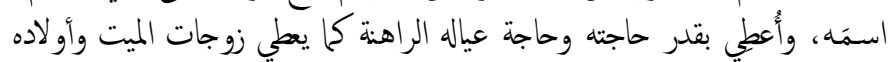

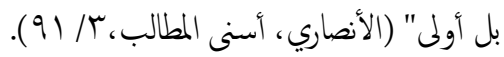

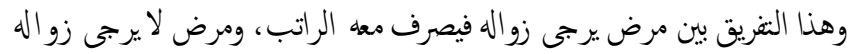

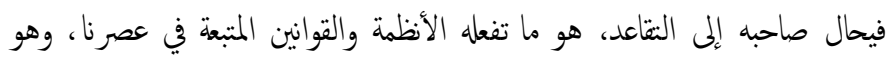
الأوفق لمقاصد الحق ومصاح المالح الخلق.

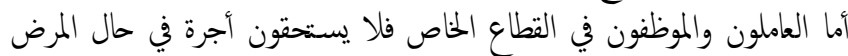

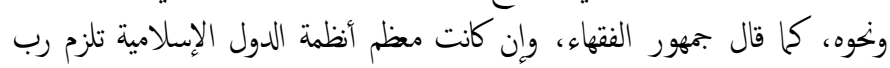

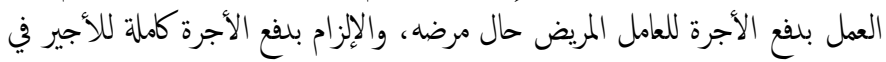

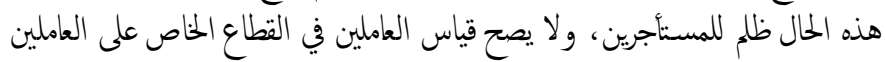

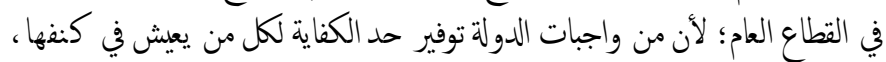

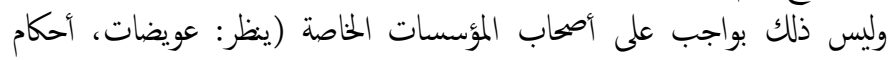

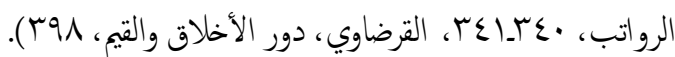

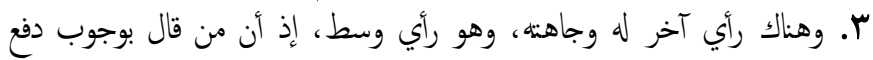

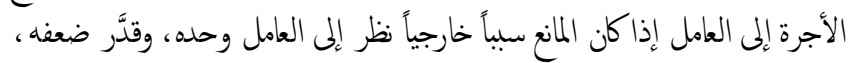

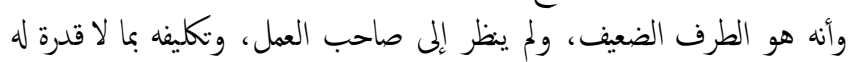

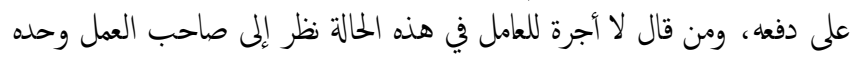

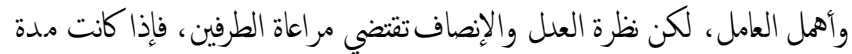

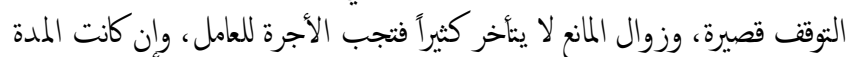

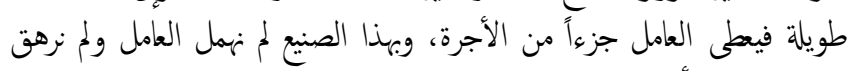

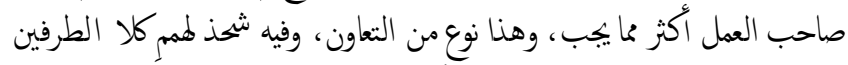

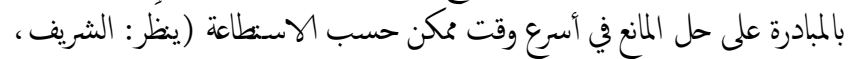

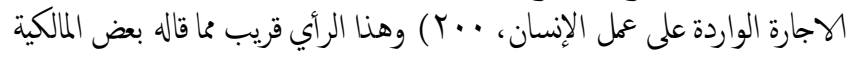
كما تقدم في القول الثاني. والله تعالى أعلم بالصواب العول الني.

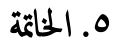
فيما يأتي أهم النتائج والتوصيات التي توصل اليها البحث:

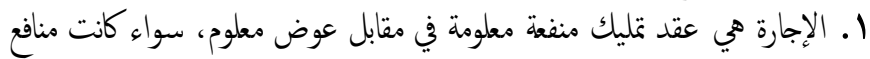

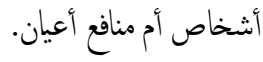




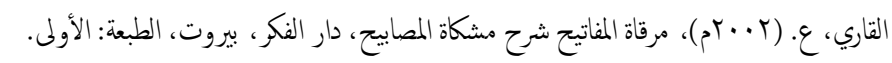

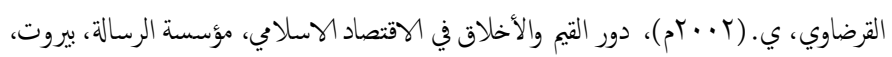

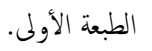

القرطبي، م. (ب. - آم)، الجامع لأحكام القرآن، المحقق: هشام سمير البخاري، دار عالم الكتب،

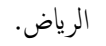

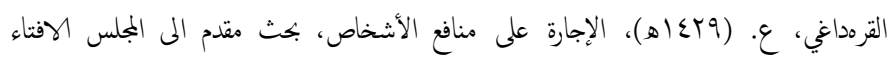

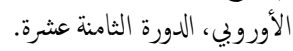

الكاساني، أ. (ד/91/م)، بدائع الصنائع في ترتيب الشرائع، دار الكتب العلمية، بيروت، الطبعة: الثانية.

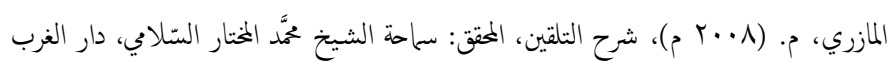
الاسلامي، تونس، الطبعة: الثانية.

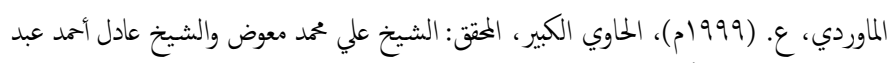

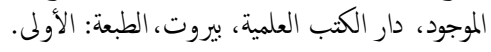

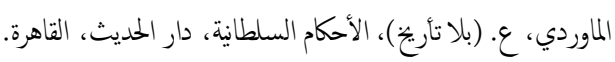

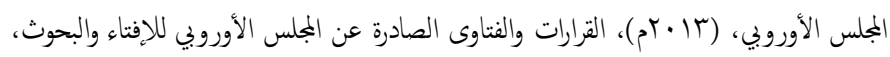

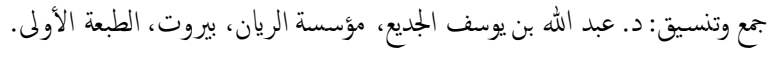
مجمع اللغة العربية، (بلا تأريخ)، المعجم الوسيط، دار الدعوة، القاهرة.

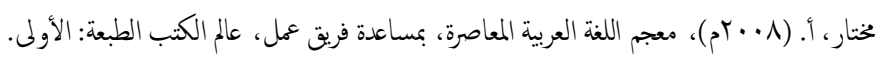

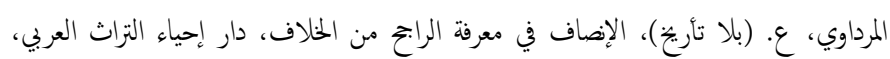
بيروت، الطبعة: الثانية.

المرغيناني، ع. (بلا تأريخ)، الهاية في شرح بداية المبتدي، المحتق: طلال يوسف، دار احياء التزاث العربي، بيروت. (كوتان

المواق، م. (ع 1991)، التاج والإكليل لمختصر خليل، دار الكتب العلمية، بيروت، الطبة: الأولى.

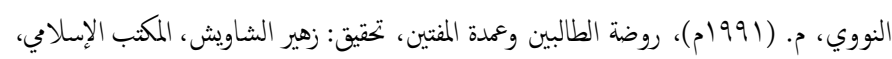
بيروت، الطبعة: الثالثة.

هيئة المحاسبة والمراجعة، (ع البمام) المعايير الشرعية، طبعة مصرف البركة.

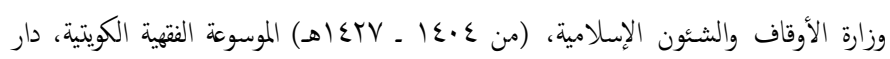
السلاسل، الكويت، الطبعة الثانية.
ابن ماجه، م. (بلا تأريخ)، سنن ابن ماجه، تحتيق: محمد فؤاد عبد الباقي، دار إحياء الكتب العربية، فيصل عيسى البابي الحلبي.

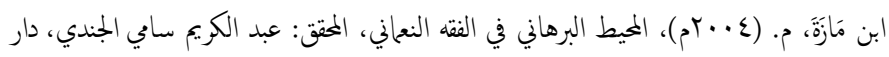

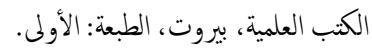

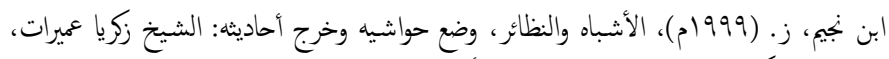
دار الكتب العلمية، بيروت، الطبةة: الأولى.

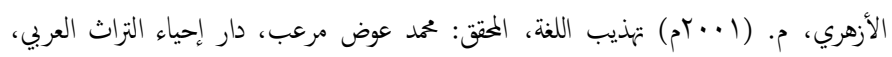
بيروت الطبعة: الأولى. - ميل.

الأضاري، ز. (بلا تأريخ)، أسنى المطالب في شرح روض الطالب، دار الكناب الإسلاي، بيروت. الههوتي، م. (بلا تأريخ)، كشاف القناع عن متن الإقناع، دار الكتب العلمية، بيروت. حسن، أ. (ץ . آم) ظرية الأجور في الفته الاسلاي، دار اقرأ، دمشق، الطبعة الأولى.

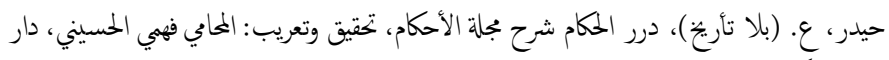

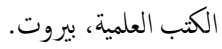
الخرشي، م. (بلا تأريخ)، شرح ختصر خليل، دار الفكر للطباهة، بيروت.

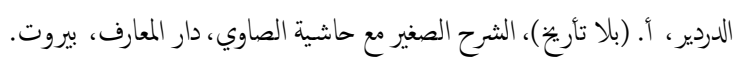

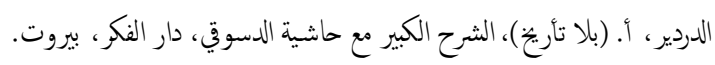

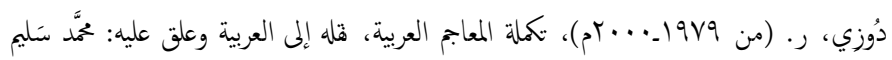

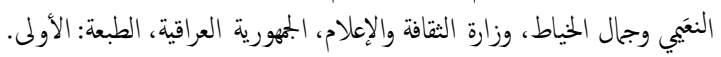

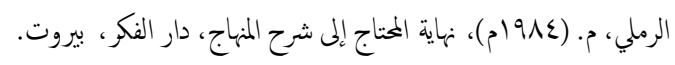

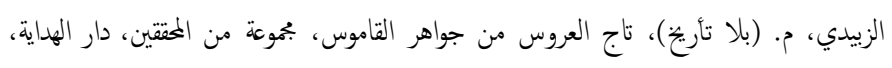

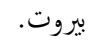
الزيلي، ع. (rآ/اهـ)، تبيين الحقائق شرح كنز الدقائق وحاشية الشبلي، المطبعة الكبرى الأميرية، القاهرة، الطبعة: الأولى.

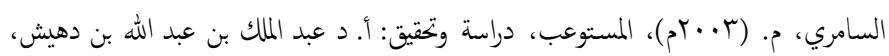
مكلة المكرمة.

$$
\text { السرخسي، م. (بوام)، المبسوط، دار المعرفة، بيروت. }
$$

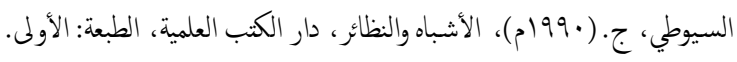

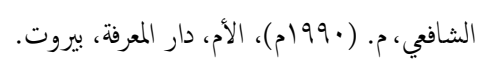

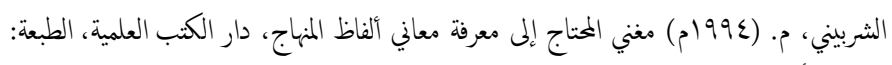
الأولى.

الشريف، ش. (بلا تأريخ)، الإجارة الواردة على عمل الإنسان ـ دراسة مقارة، رسالة دكتوراه مقدمة

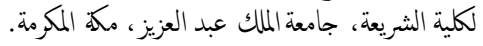

$$
\text { الشيرازي، إ. (بلا تأريخ)، المذذب في فقه الإمام الشافي، دار الكنب العلمية، بيروت. }
$$
العراقي، ع. (بلا تأريخ)، طرح التثريب في شرح التقريب، الطبعة المصرية القديمة.

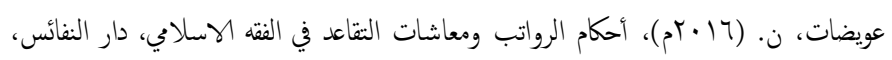

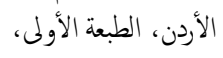

العيني، م. (.. (Tم)، البناية شرح الهاية، دار الكنب العلمية، بيروت، الطبعة: الأولى.

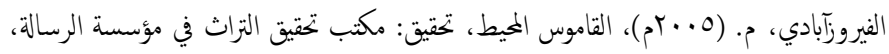

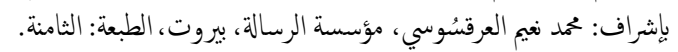

